\title{
HIGH-PRESSURE WATER-POWER WORKS
}

BY Mr. L. ZODEL, OF ZÜRICH.

\section{[Translated from the German.]}

In selecting this as the subject of the present Paper, it is not the intention of the author to lay down rules and principles which govern the design and construction of high-pressure water-power works, but rather to review the progress made in such plants of recent years and to endeavour to bring forward the relative merits of different designs for different purposes. Keeping this object in view, reference will be made to a number of modern plants, short descriptions of which will become necessary in this Paper in order that members may be acquainted with the particular conditions governing those plants, although many may be already familiar with the characteristics of some of them. Illustrations in the way of slides will form an important part and will be necessary to make the subject-matter clear; they will show that hydro-electric stations, of all things, lend themselves the least readily to hard and fast rules, and it by no means follows that what has shown itself satisfactory in one case will be equally satisfactory in another. Engineers of every branch will be represented on work of this kind, and surveyors, architects, miners, railroad men, besides engineers of the mechanical and electrical 
professions, have to work hand in hand, in order to secure the best results. In some cases geologists and even weather prophets have to be consulted.

The utilization of high-pressure water-powers represents the latter portion of the wonderful and rapid development which has occurred in hydraulic works during the last twenty years. This is largely owing to the fact that such powers are necessarily in mountainous districts, and may be at some considerable distance from thickly populated centres where a demand exists for power for lighting, traction, and industrial work. Therefore comparatively low falls were more in use until the question of long-distance high-tension electrical transmission could be looked upon as a sound technical and commercial proposition. This has only been satisfactorily solved within the last few years.

At the Frankfurt Exhibition of 1891, a power transmission at Laufen-on-the-Neckar, over the then extraordinary distance of $175 \mathrm{~km}$. (108 miles), was brought into actual use, and proved that transmissions over still greater distances were equally possible and were only a question of time. This laid the foundation stone for present day high-tension electrical transmission. But at that time only a couple of hundred horse-power were dealt with, and it required much hard work, with innumerable tests and many failures, before the thousands or even hundreds of thousands of horse-power could be transmitted safely within the requisite economical limits, over distances exceeding $200 \mathrm{~km}$. (125 miles).

It is necessary to divide water-powers into three classes, namely, low, medium, and high head. Certainly there is no well-defined limit, but for general convenience we may call low-pressure plants those with a head of from 1 to $10 \mathrm{~m} .(32 \cdot 8$ feet) or to perhaps $15 \mathrm{~m}$. (49 feet); medium pressure those from 10 to $100 \mathrm{~m}$. (328 feet); and high pressure those over 100 or $200 \mathrm{~m}$. (656 feet). The waterturbine builder has a much sharper and more precise distinction. He calls low-pressure plants those in which the turbines are placed in open flumes; medium-pressure those in which the turbine is placed in closed casings (such as pipes, drums, spirals, etc.); and high-pressure those in which impulse-wheels are employed. 
It is also possible to classify such plants according to the volume of water utilized. Thus with the same head a station might be termed medium-pressure or high-pressure according as the discharge utilized was large or small. A plant with, for example, 100 metres head and a very large volume of water, say $20 \mathrm{~m}^{3}$. (716 cubic feet) per second, would be considered one of medium head, because a closed reaction turbine having a draught tube would be employed; yet the same head with only $1 \mathrm{~m}^{3}$. (35 cubic feet) per second would certainly constitute a high-pressure plant, for impulse turbines would be installed.

High-pressure plants usually work out considerably cheaper than low-pressure for the same power, but a long transmission-line may so increase the capital outlay on the former that a low-pressure station nearer the consumer is preferable. All such questions must be carefully worked out for the particular case in hand.

A very great advantage possessed by high-pressure plants over low-pressure, and shared to a large extent by medium-pressure also, is the readiness with which the irregular flow of rivers may be regulated to supply a constant-power demand, by means of storage reservoirs and weirs. With these it becomes possible to utilize the whole of the rainfall of a district and to store the water till required by the power consumer. Thus we may say that such storage plants are by far the more rational proposition. Storage however increases the cost of a station very considerably, and the amount of such storage must be limited to such capital charges as will be borne by the plant as a paying concern. The greater the head of water, the more rational will a storage reservoir be, since the same quantity of accumulated water will represent a proportionately larger store of energy.

Questions of national economy, and of political or even strategic importance are often served by water-power stations, besides the immediate interests of the promoters of the scheme. This is especially the case in countries such as Switzerland, which have no coal or other natural fuel, and have to depend on foreign States for their supply; hydro-electric stations represent the foundation of their industrial security and independence. 
Many large high-pressure stations with both natural and artificial storage reservoirs have been built within the last few years all over the world. Some of these will now shortly be brought to the notice of members, reference being more particularly made to the pipe-lines and conduits carrying the water from the lake or river to the turbines.' For it is exactly to these pipe-lines that too little attention is usually devoted. Many people, and not a few engineers, consider that the pipe-line is a secondary part of a hydraulic power plant, so long as the thickness of the pipe allows a good factor of safety against the pressure, and a continuous line has been laid over the ground from the intake to the turbine. Hence it is that pipe-lines are often built by engineers who are experts in the choice of material and in the manufacture of a pipe, but who do not understand the essentially important functions which a complete pipe-line, and especially a high-pressure pipe-line, has to fulfil. The general arrangement, the relative dimensions of different parts of the pipe-line, and the methods of anchoring and placing of fixed points, are all such important factors that they can only be properly determined by the turbine builder, because on them depends to a very great extent the proper working of the turbine and hence the success of the whole plant.

The Necaxa Power Works, Plates 38 and 39.-The works of the original Necaxa power-station of the Mexican Light and Power Co. have been fully described in various technical journals and will no doubt be familiar to members. During the last two years, however, very great enlargement of the plant has taken place, which is of such interest as to justify a description in this Paper. A short account of the old works will, however, be necessary so as to recall the main features of the station.

The Mexican Light and Power Co. was founded by Dr. Pearson in Montreal in the year 1902 for the purpose of developing the water-power of the Necaxa and neighbouring streams in the State of Hidalgo, and of transmitting the power a distance of $150 \mathrm{~km}$. (93 miles) to the city of Mexico and to other towns. The magnitude of the work undertaken by this company may. be judged from the 
fact that the share capital interested is $\$ 16,000,000$, and that the total funds at its disposal are brought up to nearly $\$ 30,000,000$ by issues of bonds.

The Necaxa river flows over an extensive plateau of the Mexican table-land, and at one part of its course descends abruptly in a series of falls for a height of over $400 \mathrm{~m}$. (1,312 feet) into a deep valley. This head is utilized for the power works. The first part of the scheme, which was commenced in 1903, consisted of the construction of a large earth dam above the falls to form a storage reservoir which supplied the power-station with water for about 50,000 h.p. This station was in operation by the end of 1905 , but the final completion of the dam was delayed to this year by the collapse of the inner face owing to the thrust of water collected within the dam when the reservoir was empty. This accident interfered with the working of the power-station for some time. The maximum height of the dam is $60 \mathrm{~m}$. (197 feet); greatest length $390 \mathrm{~m}$. (1,279 feet), and the greatest breadth $290 \mathrm{~m}$. (951 feet) at the base; it required a total volume of $1,600,000 \mathrm{~m}^{3}$. (2.08 million cubic yards) of material to complete. A puddle core was employed and much of the material was sluiced into place hydraulically. The capacity of the Necaxa reservoir is $45,000,000 \mathrm{~m}^{3}$. (1,590 million cubic feet). An earth dam was selected as the type most suitable for the volcanic nature of a country periodically liable to earthquakes.

The plan in Fig. 1 (page 622) shows the general lay-out of the plant. Two large feeder pipes of $1.82 \mathrm{~m}$. (6 feet) diameter start from the intake tower, situated in the lake beyond the dam, and pass through a tunnel which emerges below the dam wall. These two feeders are made of riveted plate and are laid on concrete pedestals, partly in cuts and partly in tunnels to a receiver-pipe of $7 \mathrm{~m}$. length and $2.5 \mathrm{~m}$. diameter, under a pressure head of $54 \cdot 2 \mathrm{~m}$. (177.8 feet). From this receiver the six high-pressure pipes descend in a tunnel through the cliff to the power-house. Sluice-valves are provided at the receiver to control each pipe, and air-pipes are laid from behind the valves on each high-pressure line up the bill at the entrance to the pipe tunnel to a height above that of the reservoir 
level. The six pressure-lines are laid in two parallel tunnels; they are composed of welded pipes of $781 \mathrm{~mm}$. (30.7 inch) outside diameter, and have a thickness varying between 10 and $22 \mathrm{~mm}$. $(0.39$ and 0.87 inch) with a total length of $735 \mathrm{~m} .(2,411$ feet $)$ to the turbines. The maximum static head is $432 \mathrm{~m}$. (1,417 feet).

FIG. 1.

Plan and Profile of Pipe-Line. Necaxa.

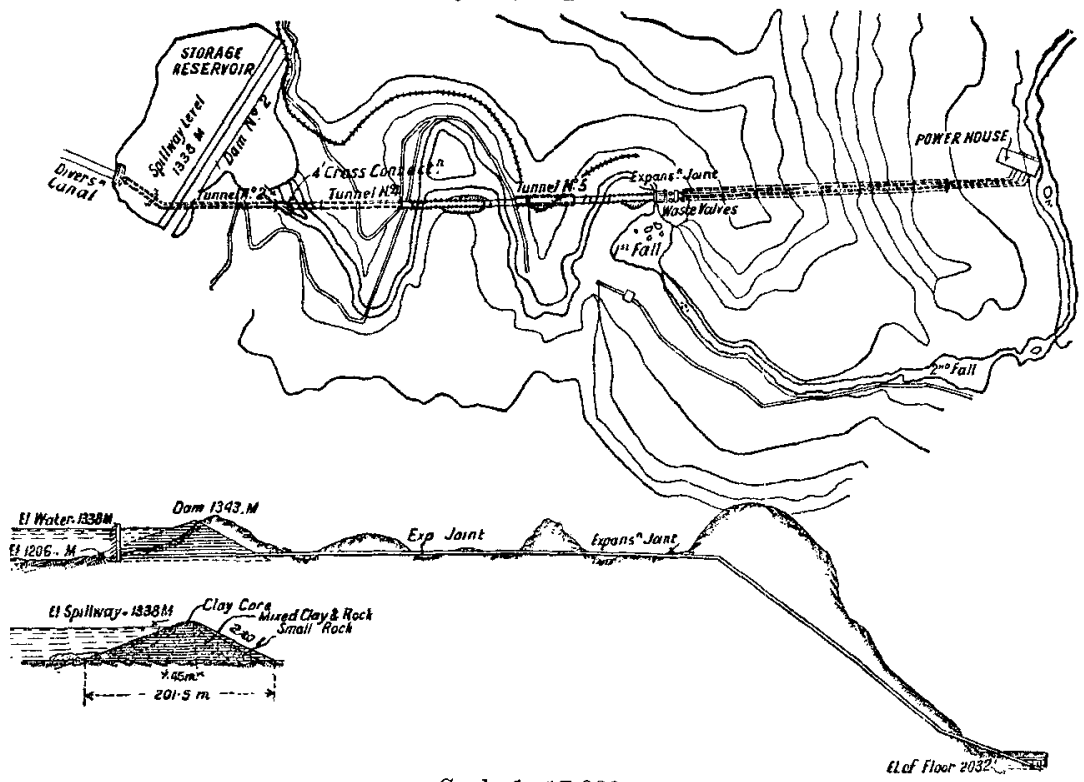

Scale $1: 17,000$.

The turbines were Escher, Wyss \& Co.'s impulse-wheels designed for a net head of 360 to $390 \mathrm{~m}$. (1,181 to $1,279 \mathrm{feet})$ to generate 8,200 h.p. at 300 revolutions per minute. They are arranged with vertical shafts which also carry the generator rotors, and are supported by an oil-pressure thrust-bearing. Three-throw oil-pumps connected to an air-vessel supply pressure-oil to the bearings and governors. A pressure-relief valve is fitted to each turbine to prevent shocks in the pipe-line. 
Having thus recalled to mind the conditions of the original plant at Necaxa, the author will proceed to describe the extensions, which are now in part completed and in part still under construction.

The company have greatly increased the water available by diverting the Texcapa, Tenango, Nexapa, and Xaltepuxtla rivers into the Necaxa reservoir by means of an extensive system of tunnels through the dividing ridges. The eatchment area has thus been raised to $400 \mathrm{~km}^{2}$. (154 square miles), and can shortly be further increased by another $200 \mathrm{~km}^{2}$. (77 square miles) by bringing in the large Laxaxalpan stream. The additional storage volume required has been obtained by the construction of a series of earth dams of very great size, forming reservoirs on each of the streams with capacities as follows:-

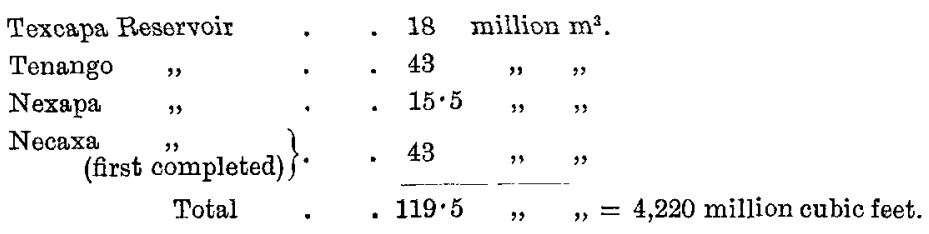

Thus the present storage capacity of the combined system is nearly $120,000,000 \mathrm{~m}^{3}$. Further schemes provide for an ultimate development of the Los Reyes, Laguna, and other reservoirs which would bring up the total capacity to over 300 million $\mathrm{m}^{3}$. and at the same time considerably increase the catchment area.

As a first step towards the enlargement of the power-house plant the company decided to increase the capacity of the existing six 8,200-h.p. turbines to 11,000 h.p. each, by fitting new runners and new nozzles, Fig. 4 (page 624). This was successfully carried out, and is an interesting case, since the velocity of the water in each of the six pipe-lines supplying the six turbines was thereby increased to $5.5 \mathrm{~m}$. (18 feet) per second. This is an exceptionally high figure, but was not found to be injurious in any way. The capacity of the station thus became 66,000 h.p.

The next step was the erection of two new units of 16,000 h.p. each, built by Escher, Wyss \& Co. They are similar in design to 
FIG, 4 .

11,000 H.P. Turbine and Generator. Necaxa.

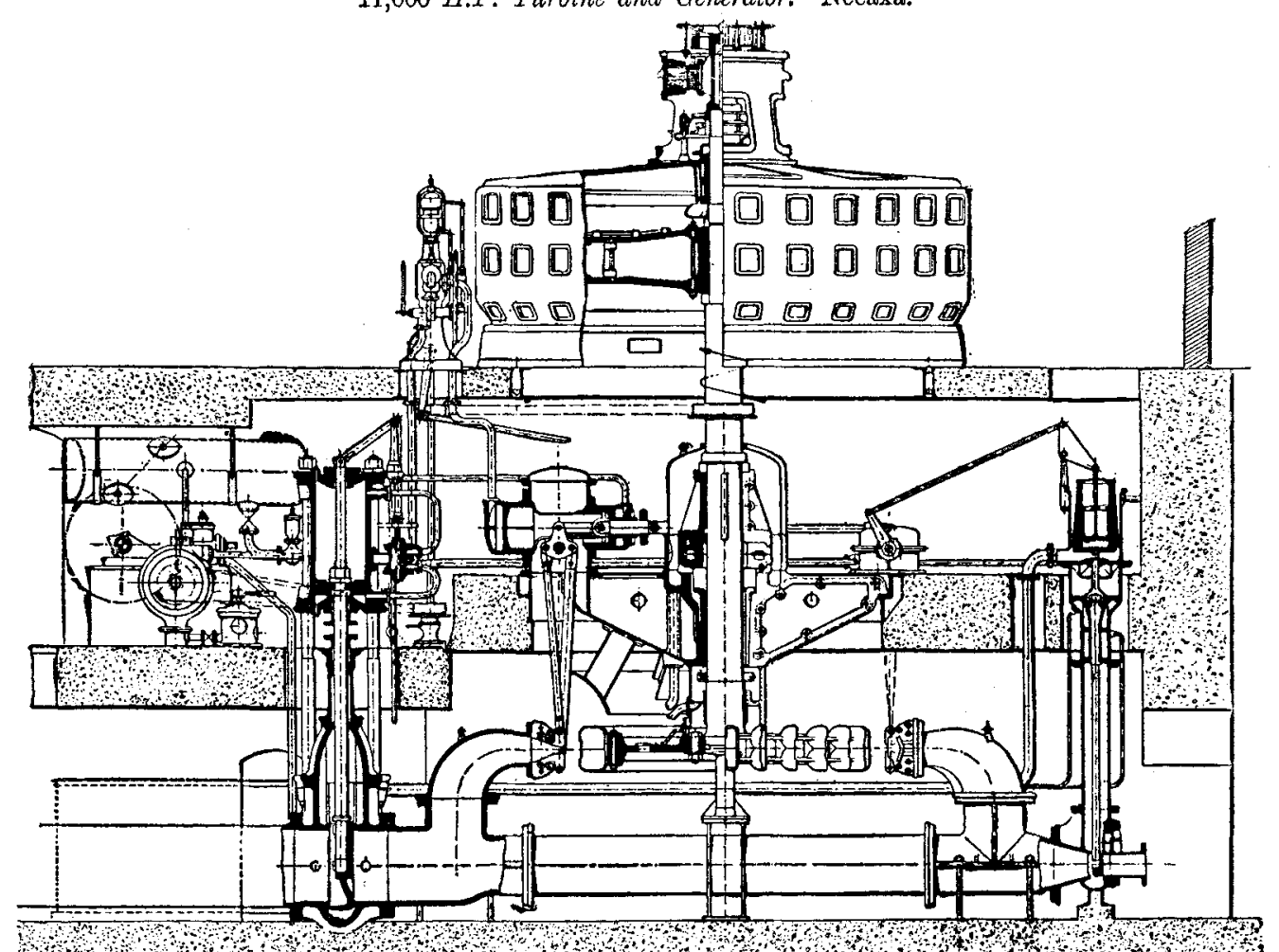


the old machines, and are supplied with water through a new pipe-line system which has been just recently erected. A new low-pressure feeder-pipe starts from the intake tower in the Necaxa reservoir and joins with another feeder which is arranged to draw water directly from the conduit, Fig. 2, Plate 38, connecting the Tenango and Necaxa basins. Inter-connecting valves are arranged between these feeders as the illustration shows. The new feeder is laid in cuts and tunnels parallel to the first to a receiver from which the two new pressure pipe-lines descend in a separate tunnel to the power-house. The two high-pressure pipes are arranged in four sections of $1,160,1,100,1,075$ and $1,040 \mathrm{~mm} .(46,43,42$ and 41 inches) diameter respectively, having a total length of about $680 \mathrm{~m}$. (2,230 feet). The maximum velocity in these pipes is $4.7 \mathrm{~m}$. ( $15 \cdot 4$ feet) per second. The new pipe-line system is thus almost a completely parallel construction with that first built, and is in every way similar, though on a considerably larger scale. The capacity of the power-station is now 98,000 h.p.

Rio de Janeiro Pover Plant, Plates 40-42.-The power works of the Rio de Janeiro Tramway, Light and Power Co., which now supplies the entire city, having a population of 812,000 , with light and power, is situated on the Lages river at a distance of $80 \mathrm{~km}$. (50 miles) from the metropolis. The useful watershed comprises an area of $500 \mathrm{~km}^{2}$. (193 sq. miles), all of which lies within $100 \mathrm{~km}$. (62 miles) from the coast, and has an average though irregular tropical rainfall of $1,500 \mathrm{~mm}$. (59 inches) a year. The Rio das Lages pursues a course through a tortuous valley having a very slight fall for a great distance, and then suddenly descends in a succession of falls and rapids a height of over $300 \mathrm{~m}$. (984 feet) in a distance of only a few kilometres. This gives a very favourable situation for a hydro-electric station combined with a storage reservoir. The natural flow of the Rio das Lages varied between a minimum of $2-2 \frac{1}{2} \mathrm{~m}^{3}$. (70-88 cubic feet) per second and a maximum of $600 \mathrm{~m}^{3}$. (21,190 cubic feet) per second, with an average of $13 \mathrm{~m}^{3}$. (460 cubic feet) per second, which is sufficient for 40,000 h.p. continuously with a head of 310 metres. 
An artificial storage reservoir, with an area of $18.6 \mathrm{~km}^{2}$. ( 8 sq. miles) and mean depth when full of $11 \cdot 34 \mathrm{~m} .(37 \cdot 2$ feet), has been formed by building an arched concrete dam across the narrow valley above the place where the rapid fall begins. Granite rock was quarried near the site of the dam. Fig. 5, Plate 40, illustrates the completion of the spillway along the crest of the dam wall :-

\begin{tabular}{|c|c|c|c|c|}
\hline Maximum height of dan & . & & \multicolumn{2}{|c|}{42 metres } \\
\hline Thickness at base & . & . & 27 & , \\
\hline Radius of dam (mean) & . & . & . 150 & , \\
\hline Length along crest & . & . & . 220 & , \\
\hline Length of spillway & & & . 135 &, \\
\hline \multicolumn{2}{|c|}{ Elevation of spillway above the sea } & & . 404 &, \\
\hline Volume of concrete in $\mathrm{d}$ & & & 60,00 & $\mathrm{~m}^{3}$ \\
\hline
\end{tabular}

This lake is the largest artificial reservoir formed by a dam wall at present in existence. It has a total volume of 222 million $\mathrm{m}^{3}$. $\left(7,840\right.$ million cubic feet), and a total useful volume of 204 million $\mathrm{m}^{3}$. (7,206 million cubic feet) obtained with a maximum variation of water-level of 19 metres, which represents the difference in elevation of the water intakes. The length of lake is $27 \mathrm{~km}$. (17 miles), and the total circumference about $220 \mathrm{~km}$. (137 miles) owing to the extremely tortuous character of the contours. The steep sides of the valley gave an excellent site for the dam, which is thus of very economical proportions for the water-storage volume obtained.

The power-house is situated at an elevation of $94 \mathrm{~m}$. (308 feet), giving a gross maximum head of $310 \mathrm{~m}$. (1,015 feet). The loss of hend by friction in the feeders is reckoned at $6 \cdot 6$ per cent., so that the maximum net head at the turbines becomes $290 \mathrm{~m}$. (952 feet). The difference in the hend when the reservoir is full and nearly empty is less than 6 per cent.

The water-tower for the intake at the reservoir, seen in Plate 40 , is arranged in three levels, each provided with screens and gates 9 feet by 12 feet, so as to draw the water from the surface at all levels of the lake. A separate intake is arranged for each of the two 8-foot feeders passing from the reservoir, so as to make each half of the system perfectly independent.

The pipe-line has a great similarity to that of Necaxa, and is 
made in two sections, consisting of two upper low-pressure pipes and of six main high-pressure pipes for the lower portion leading to the power-house. Connection is made between these sections by means of a receiver-pipe, which serves the purpose of a penstock chamber in power works having an open conduit to convey the water to the pipe-lines.

This upper system of pipes consists of two independent riveted steel feeder-pipes $2,435 \mathrm{~mm}$. ( 8 feet) in diameter with a total length of $1,684 \mathrm{~m}$. (5,530 feet). These form an interesting feature, as at Necaxa, in that they replace the open flume or conduit which up to the present has been the more usual construction, but would have caused considerable difficulty here. The steel feeder-pipes have the great advantage that being under pressure they utilize the full head obtained at all times in the reservoir. They are built of plate varying in thickness from $6.4 \mathrm{~mm}$. to $16 \mathrm{~mm}$. ( $\frac{1}{4}$ inch to $\frac{\pi}{8}$ inch) and are under a maximum pressure-head of $56 \cdot 78 \mathrm{~m}$. (186 feet). The average fall of the pipes varies from 0.15 per cent. to 9 per cent.; they pass through three tunnels with lengths of 187 , 88 , and 436 metres; a valley is crossed by means of an inverted siphon 131 metres long and 29 metres deep, shown in Fig. 7, Plate 41. At about half-way between the intake and the receiver, at the exit of the third tunnel, each pipe is provided with an 8-foot stand-pipe, open to the atmosphere $16 \mathrm{~m}$. (52 feet) high, carried above the spillway level, for the purpose of equalizing any pressure oscillations due to water-hammer. The two feeders each connect to a receiver-pipe under a pressure-head of 57 metres at an elevation of 347 metres, and a second pair of stand-pipes 8 feet in diameter are taken up the side of the hill to the same height as the other two, in order to equalize pressure oscillations at this point; they may be seen above the valve-house. A valve-house is provided, enclosing the two receiver-pipes and containing a $2,435 \mathrm{~mm}$. (8-feet) sluicevalve on each feeder, a $1,525 \mathrm{~mm}$. (5-feet) valve between the two feeder $s$, and $915 \mathrm{~mm}$. (3-feet) valves at the top of each pressure-pipe leading from the receivers to the power-house. The latter valves can be closed by little Pelton-wheel turbines, supplied with water from the receiver and started by solenoids actuated from the 
power-house, so that water can be quickly shut off from the $915 \mathrm{~mm}$. (3-feet) pipes in cases of emergency.

Three lines of high-pressure $915 \mathrm{~mm}$. (3-feet) pipes start from each receiver, and each of the six lines connects to a 9,000-h.p. turbine. A seventh pipe-line of $305 \mathrm{~mm}$. (1 foot) diameter passes from both receivers to drive the exciter turbine sets. The main high-pressure pipe-lines have a thickness of from 10-26 $\mathrm{mm}$. $(0 \cdot 4-1 \cdot 02$ inches) and are 670 metres long; the pipes are lap-welded steel of 10 metres length with flanged ends held together by loose rings. A $150-\mathrm{mm}$. (6 inches) stand-pipe, carried above the spillway level, is provided on each high-pressure pipe-line just behind the sluice-valves next the receiver, so that the whole arrangement with the pressure-receivers approaches the conditions of an open penstock chamber and has been eminently satisfactory. The whole pressure system is divided into two completely separate and self-contained units, and this provides great safety in operation. The velocity of flow in the pipes is $4.4 \mathrm{~m}$. per second.

The power-house illustrated in Fig. 8 , Plate 41 , is constructed entirely of steel and concrete, 72 metres long, 29 metres wide and 24 metres high; 2,500 tons of steel were used.

The six turbines are impulse-wheel machines built by Escher, Wyss and Co, with vertical shaft and four needle-nozzles symmetrically arranged round the cast-steel wheel-dise, which has an effective diameter of $2,120 \mathrm{~mm}$. (84 inches) and is provided with eighteen cast-steel buckets. They are designed for a head of 273-290 metres and generate 9,000 h.p. at 300 revs. per min. An oil-pressure thrust-bearing supports the turbine and generator rotors, which amount to 40 tons dead weight. These bearings are supplied with pressure-oil by three-throw pumps, which also feed the turbine governors. A pressure-relief valve is arranged to limit rise of pressure in the pipes to 10 per cent. on throwing full load off the turbine. Two exciter units of 400 h.p. each are provided.

The generators supply three-phase current at 6,000 volts and 50 cycles, which is stepped up through transformers to a line voltage of 88,000 for transmission to Rio de Janeiro, the distance being $88 \cdot 5 \mathrm{~km}$. (55 miles). 
Up to the present time turbines developing a total of 54,000 h.p. have been installed, and sanction has just been given for a further increase of two units of 19,000 h.p. each.

Tyssedalen Station, Plates 43 and 44.--Power works of very special interest have been recently erected in Norway, and of these one will be mentioned by reason of the difficult work carried out on the pipe-line. This is the power-plant at Tyssedalen, nenr Odda, the Hardanger Fjord on the west coast, where 33,600 h.p. are now utilized and transmitted to Carbide, Cyanamide, and other factories at Odda, a distance of about $6 \mathrm{~km}$.

The source of power is the Tysse River, on which is the famous Skjeggedahlsfos, one of Norway's most beautiful waterfalls. Below this fall is the Ringedals Lake, which provides an ideal natural storage reservoir for the power-works at an elevation of $435 \mathrm{~m}$. $(1,426$ feet) above and at $3 \cdot 5 \mathrm{~km} .(2 \cdot 17$ miles $)$ distant from the Fjord, at whose edge the power-house is situated. This lake has an area of $5 \cdot 5 \mathrm{~km}^{2} .(2 \cdot 22 \mathrm{sq}$. miles), and has now been tapped by a regulating tunnel of $6 \mathrm{~m}^{2} .(64 \cdot 5 \mathrm{sq}$. feet) area at a depth of $16.5 \mathrm{~m}$. (52 feet) below the normal level; by this means a useful storage capacity of about 80 million $\mathrm{m}^{3}$. $(2,825$ million cubic feet) has been obtained by allowing the level to be drained to this depth during the winter months when the flow of the river is at a minimum. A dam has also been constructed to raige the waterlevel by $13.5 \mathrm{~m}$. (44.5 feet) to a maximum elevation of $448.5 \mathrm{~m}$. $(1,470$ feet $)$, and the useful storage volume is thus 170 million $\mathrm{m}^{3}$. (6,000 million cubic feet). The catchment area of $378 \mathrm{~km}^{2}$. (146 sq. miles) is sufficient, with the ample rainfall in this mountainous district, to give about 100,000 h.p.

The regulating tunnel from the Ringedals Lake discharges into the little Vetle Lake, immediately below, which forms a second small regulating basin on the river, whose level is adjusted by a needle-dam. A tunnel of $3,410 \mathrm{~m}$. (11,200 feet) length starts from this lake and passes through the mountain to the penstock chamber, from which the pipe-line leads down to the power-house. This tanael is driven through granite for the whole of its length, the 
work having been carried on simultaneously from thirteen adit levels, and was completed within 2 years. The rock was left rough inside the tunnel, the cross section being nowhere less than $9.5 \mathrm{~m}^{2}$. (102 square feet).

The penstock chamber is cut out of the solid rock to a depth of about $15 \mathrm{~m} .(49 \cdot 3$ feet), and the tunnel emerges into the bottom of this at an elevation of $397 \cdot 5 \mathrm{~m} .(1,303$ feet). The sill of the overflow of the penstock is at elevation $413 \mathrm{~m}$. (1,353 feet) and the maximum possible water-level due to the head in the tunnel is $415 \mathrm{~m}$. (1,360 feet).

Two pipe-lines of $1,600 \mathrm{~mm}$. (63 inches) diameter connect with this penstock chamber through a short tunnel, and are fitted with sluice-valves of $1,200 \mathrm{~mm}$. (47 inches) diameter placed in a valvehouse at the exit. Flap-valves are also arranged over the end of the pipes in the chamber in such a way that the chains which hold them open may be released by electric current from the power-house, in case of accident to any part of the plant. The intake would then be closed immediately by shutting the flap. The usual air-pipes are fitted to prevent the formation of a vacuum on emptying the pipe-line.

The two pipe-lines already installed are arranged in three sections of $1,200,1,100,950 \mathrm{~mm}$. $\left(47,43 \frac{1}{2}, 37 \frac{1}{2}\right.$ inches) diameter respectively, and have a thickness varying between $7-23 \mathrm{~mm} .\left(\frac{9}{16}-\frac{7}{8}\right.$ inch $)$. The total length is $720 \mathrm{~m}$. (2,360 feet). They are made of single and double-riveted pipes. The illustrations show the difficult character of the erection of this pipe-line, the difficulties being further increased by the necessity of carrying out a large part of the work during the winter months, the erection period being between August and March. All workmen had to be slung with ropes over the face of the rocks, and the pipes reach an inclination of $55^{\circ}$ to the horizontal, as seen in Fig. 11, Plate 43. The pipes were secured by means of $\mathrm{H}$ girders let into the cliff at the steepest part, and by massive masonry anchorage blocks built into the rock at convenient points, and reinforced with steel bars and tie rods to hold the pipes perfectly rigid. Fig. 10, Plate 43, shows the false-work for one of these anchorages, and pipes being hauled up a steep portion of 
the trolley-way which was laid alongside the pipe-line. Straight portions of the pipe-line on less steep gradients are supported by masonry pedestals with a bearing of oil-soaked paper, to facilitate small longitudinal movements due to expansion and contraction, which is taken up by expansion stuffing-box joints, placed at the top of straight sections of the line. A valve is fitted at the bottom of each pipe-line with a safety-plate so arranged as to break in case the pressure in the pipes should rise above 50 per cent. in excess of the normal. In such case the sluice-ralve behind the safety-plate could be slowly closed by hand, or the flap-valves over the pipe-line end in the penstock chamber could be instantly closed and the pipe allowed to empty itself of water, when a new safety-plate would be fitted and the line refilled. This safety-plate has been fitted to many high-pressure pipe-lines, and is a surer means of safeguarding the pipes in case of unforescen disturbances than the spring-safety valve sometimes employed, although it causes greater inconvenience if it should come into action. The pipe-line water velocity in the lower portion is $4.7 \mathrm{~m}$. $(15 \cdot 4$ feet) per second.

The distributing pipes and the branch pipes for the exciter turbines are laid along the power-house. The two pipe-lines each feed three Escher, Wyss impulse-wheel turbines of 4,800 h.p. maximum output running at 375 revolutions per minute, with a net head of $384 \mathrm{~m}$. (1,260 feet), and a seventh machine is held in reserve. These are machines with horizontal shafts and a single-needle nozzle; they are provided with pressure-relief valves for relieving pressure oscillations in the pipe-line. The generators work in parallel directly on to the 12,000-volt transmission line of $6 \mathrm{~km}$. length to Odda. Views of the turbines and generators are shown in Plate 44.

The whole station was built in the very short period of slightly over 2 years from the end of 1905 to March 1908.

An enlargement of this station is now taking place, and a third pipe-line with three zones of $1,550,1,400$, and $1,250 \mathrm{~mm}$. $(61,55$, and 49 inches) diameter is being erected to supply two turbines of 13,500 h.p. each. There was a question whether these new units 
should be arranged with horizontal or with vertical shafts, but the present-day preference for the former prevailed, and they were ordered with the horizontal arrangement. The increase in power of each unit from 4,800 to 13,500 h.p. clearly illustrates the tendency towards large units characteristic of modern turhine development. A better efficiency is thereby secured, and the cost per horse-power installed is also diminished :-

Thus this station has now $7 \times 4,800=33,600$ h.p. installed.

$2 \times 13,500=27,000$ h.p. being erected

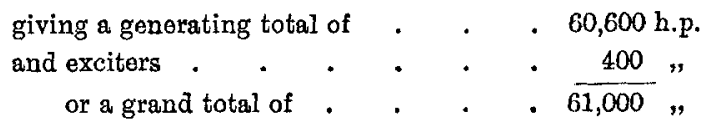

The plans for the enlargement of the station arrange for seven new sets of 13,500 h.p. each, of which the two now being built are but the first instalment. When these are finally erected, the station will have a capacity of 125,000 h.p., and the generating room will be 150 metres long.

Brusio Power Works,* Plate 45.--A typical high-pressure powerstation in Switzerland is that of the Kraftwerk Brusio Company, which utilizes the water-power of the Poschiavino River in the Poschiavo Valley in the Canton Grisons, on the south side of the Alpine Chain between the Bernina Pass and the Italian frontier near Tirano. About 55,000 h.p. are developed, the greater part of which is transmitted to the industrial districts of Northern Italy over a transmission line of $150 \mathrm{~km}$. (93 miles) length. The total head available is about $1,000 \mathrm{~m}$. (3,280 feet), and this is used in two stages. The upper stage lies between the Lago Bianco on the Bernina Pass and the Lago di Poschiavo, giving an effective head of $600 \mathrm{~m}$. (1,970 feet) for the Robbiastation; and the lower is between the Poschiavo Lake and the Italian frontier at Campo Cologno, where the head obtained is about $420 \mathrm{~m}$. (1,375 feet). The lower station was built first and will be first referred to here.

The Campo Cologno Station.-The minimum average volume of water available from the Poschiavino River has been found to be $7 \cdot 5 \mathrm{~m}^{3}$. (264 cubic feet) per second during a run of twelve hours,

* See also Noticess of Works, page 822. 
and this quantity is equalized by the Lake of Poschiavo, which acts as a natural storage basin of $2 \mathrm{~km}^{2}$. (1 25 square miles) area. A variation in level of $8.4 \mathrm{~m}$. (275 feet) is allowed by the concession, and this is obtained partly by tapping the lake below its normal level, and partly by raising the level with sluices built across the outlet. This gives a regulating volume of about $15,000,000 \mathrm{~m}^{3}$. (530 million cubic feet). The elevation of the lake is between 956 and $964 \cdot 4 \mathrm{~m} .(3,160$ feet), and is about $435 \mathrm{~m}$. (1,428 feet) above the power-house. The intake from the lake is effected by means of a siphon leading into the shaft from which the tunnel starts. The tunnel has a length of $5,250 \mathrm{~m}$., with a gradient of $1: 500$, and leads the water into the penstock chamber, Fig. 14 (page 634), excavated out of the rock, and from which the five pipe-lines descend to the powerhouse. It is of such a depth that the tunnel remains full for a distance of $1 \frac{1}{2} \mathrm{~km}$. when the plant is not working, so that sufficient water is always available for starting up the turbines; superfluous water passes to waste down an overflow situated in the tunnel. This penstock chamber is provided with screens over the pipes and with means for periodically cleaning them. Flap-valves are fitted over the ends of the pipes, and are supported when open by a chain connected to a hand-winch in such a way that it can be released by a solenoid actuated from the power-house, in the same way as at the Tyssedalen Station, and the valve allowed to fall over the end of the pipe in cases of emergency. A small hand-valve is fitted for filling the pipe-line, and the main flap-valve can then be raised by the winch gear. At a little distance below the penstock a valve-house is built, containing sluice-valves which are able absolutely to close any pipe-line, and have the usual air-pipes immediately behind them reaching to above the spillway level.

The five pressure pipe-lines now erected have a length of $981 \mathrm{~m}$. from valve-house to anchorage No. X., or, including the distributing pipes, have a maximum length of $1,124 \mathrm{~m}$., and consist of three zones of different diameters. The upper section is of riveted steel pipes $870 \mathrm{~mm}$. (34 inches) diameter, while the middle and lower sections, seen in Fig. 17, Plate 45, are of lap-welded steel plate of 830 and $790 \mathrm{~mm} .(32 \cdot 5$ and 31 inches) diameter respectively. The thickness 
Fig. 14.-Penstocti Chamber and Valve-House at top of Pipe-Lines. Brusio.

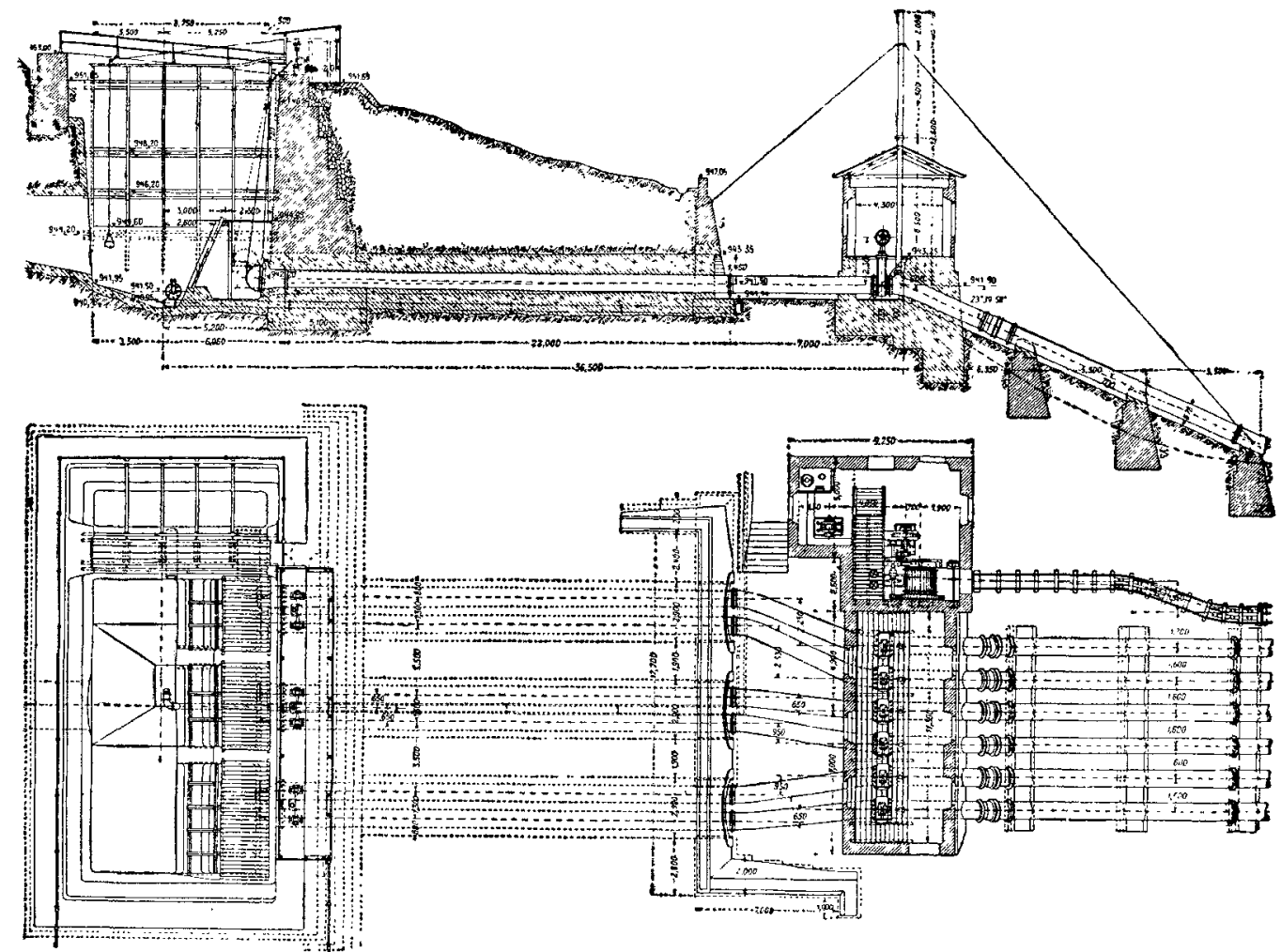


varies from 6 to $23 \mathrm{~mm}$., and the length of each pipe is $12 \mathrm{~m}$. In straight sections the pipes were each bedded on masonry pedestals, while very henvy reinforced concrete anchorages were provided at all angle points, one of these (No. X.) near the power-house having a total weight of 3,300 tons.

Each pipe is arranged to feed at least two main turbines, and the velocity of the water in the lower section is normally $3.36 \mathrm{~m}$. per second; the loss of head by friction is about $14 \mathrm{~m}$. or nearly $3 \frac{1}{2}$ per cent. Expansion-joints are arranged at the top of each straight portion of pipe-line.

Adjoining the power-house is a valve-house, Fig. 15 (page 636), containing a main throttle-valve on each pipe-line operated by gearing from the floor above; by-pass valves are provided, and drain-valves behind the throttle-valves for the purpose of emptying the water from the entire pipe-line system into the tail-race in case of stoppage of the plant.

The different pipe-lines have been connected together by means of branches to a common communication pipe laid crosswise beneath them, and in front of the throttle-valves in the power-house. This pipe serves to equalize the flow in the main pipe-lines and at present feeds the distributing pipe to the end two turbines of the power-house, since the sixth and last pipe-line is not yet installed. This is a convenient arrangement for connecting the various pipe-lines of a plant together in a case when they would be otherwise quite separated. At the end of this cross-pipe on the side towards the river, a valve with the usual safety-plate has been fitted, so as to break, should the pressure in the pipe-line system accidently rise above 50 per cent. excess of the normal. A sluicevalve has been inserted behind this valve so that the opening may be closed by hand, in case the plate should break, and thus prevent undue waste of water.

Each pipe connects up to two main turbines. The exciters have an independent distributing pipe connected to three of the pipe-lines; they can be run off any of these at will. A plan of the arrangement of the power-house is shown in Fig. 16 (page 637). 
FIg. 15.--Lower Talve-House adjoining the Power-Station. Brusio.

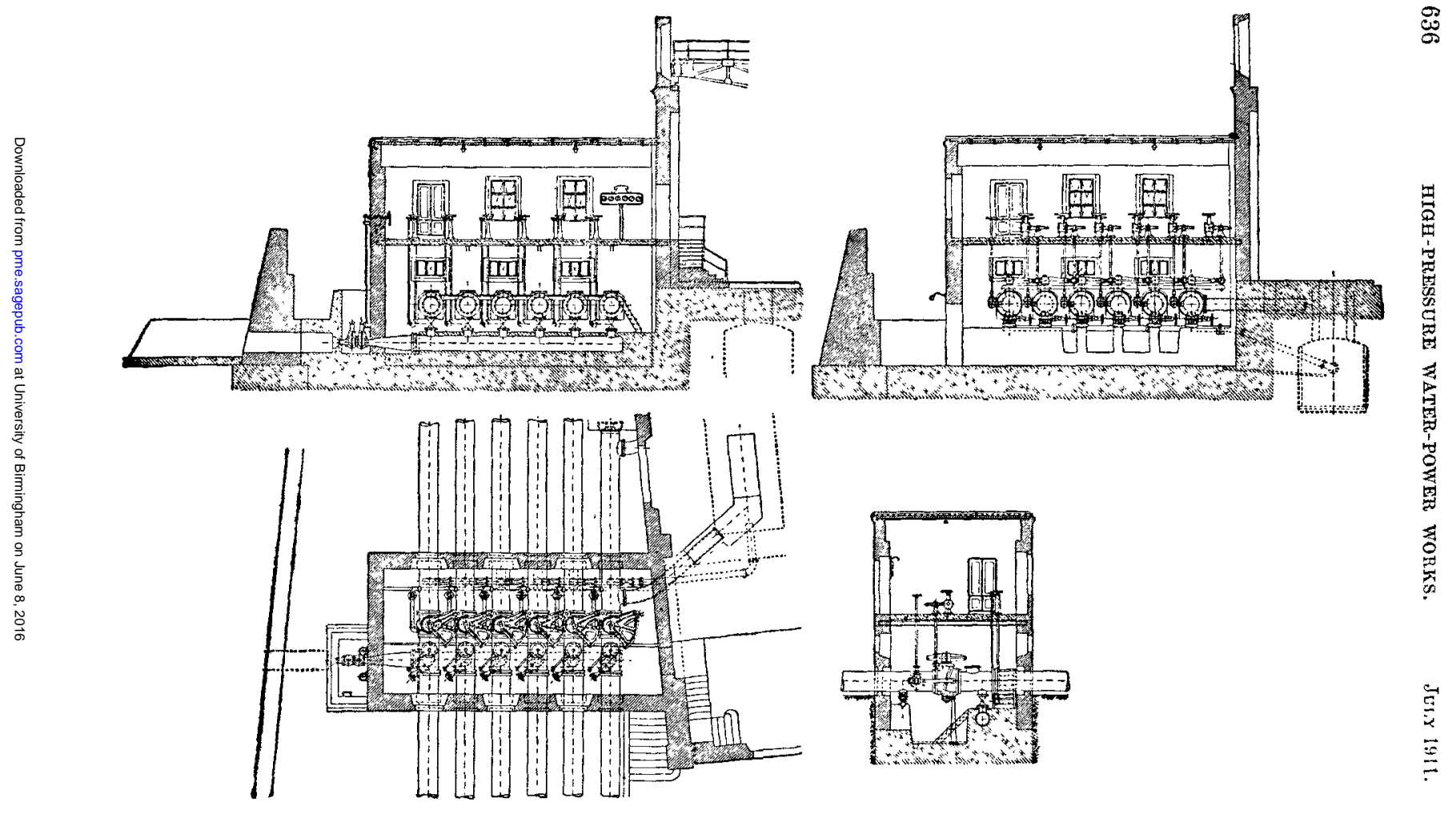


Fig. 16.-Plan and Section of the Power-House. Brusio.

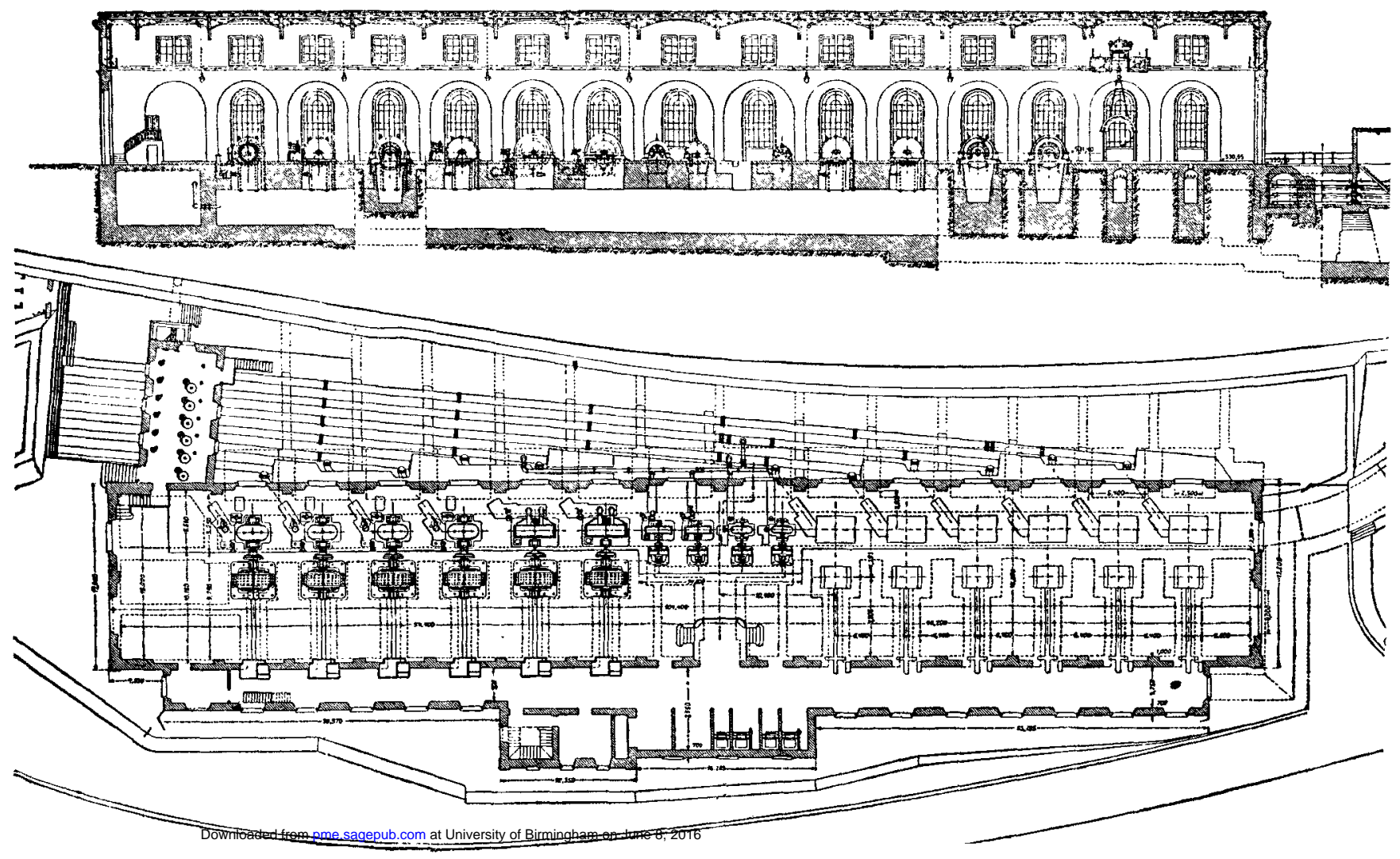


Twelve main turbines are installed in the power-house, which is situated close to the Poschiavino River. They are Escher, Wyss impulse tangential machines fitted with horizontal shaft and single needle-nozzle, with the exception of two Girard turbines which are now out of date and will shortly be replaced by the tangential type. Ten turbines are of 3,500 h.p., and two, which were put in at a later date, of 4,600 h.p., all designed for 400-metre head and 375 revs. per minute. Four exciters of 250 h.p. each bring up the total power to 45,000 h.p. Fig. 18 illustrates the main turbines. Below the needle-nozzle in this Fig. may be seen the pressure relief-valve fitted to each machine. All the machines are directly coupled to the three-phase generators which run in parallel at 7,000 volts tension and 50 periods per second. Most of this power is transmitted at 7,000 volts across the Italian frontier to the transformer station of the "Compagnia Lombarda," 500 yards distant, and there stepped up with oil-cooled transformers to a tension of 50,000 volts for the long-distance transmission system to the sub-station at Lomazzo, which supplies Como and the neighbourhood of Milan. A small portion of the power is used locally for the Bernina Railway and for power and lighting purposes in the Poschiavo Valley. During the daytime the whole station is under full load, but only a small part of it is kept running at night.

Very shortly after the completion of the Brusio Station, the demand for power grew so rapidly that the company was obliged to erect a second station to utilize the upper portion of the head to be obtained in the Poschiavo Valley.

On the summit of the Bernina Pass are two likkes, known as the Iago Bianco and Lago Nero, while on the west side of the valley the Cavagliasca stream descends from the glaciers of the Piz Palii. The Lago Bianco has an elevation of 2,230 m. (7,330 feet), that is, $1,260 \mathrm{~m}$. (4,135 feet) above the Lago di Poschiavo. The waters of the Cavagliasca have been impounded for the Robbia power-station, and the Lago Bianco, which discharges into it, has been dammed up so as to act as a storage-reservoir during winter months when the stream is frozen. Thus it was possible to obtain a head of $600 \mathrm{~m}$. 
$(1,970$ feet $)$ at the power-station, which is situated above the village of Poschiavo, and to ensure sufficient water to generate about 7,000 h.p. Three turbines of 3,500 h.p. are therefore intended for the station, of which two are now installed and one is on order. The net head is $580 \mathrm{~m}$. (1,900 feet) and the machines work at

Fig. 18.

Elevation of Generating Turbines. Brusio.

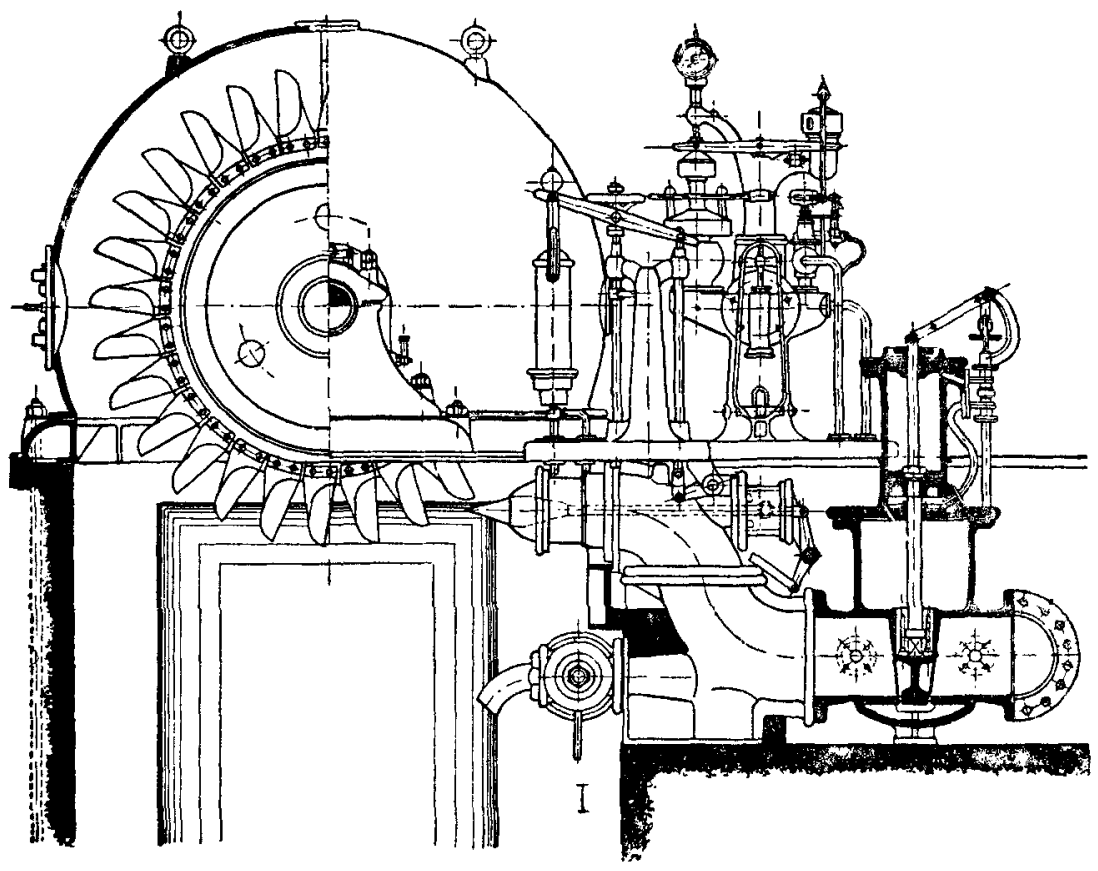

500 revs. per minute driving generator's which are run in parallel with those of the Brusio plant. A single pipe-line of $600 \mathrm{~mm}$. (23.5 inches) diameter supplies the turbines, and the velocity of flow with 7,000 h.p. running is 4 metres per second.

The turbines of this plant are fitted with the new deflecting nozzle operated by an oil-pressure governor. Similar machines are 
installed at the Adamello Hydro-Electric Power-Station, which contains a plant of exceptional interest.

The Siagne Station, Plates 46 and 47.-The River Siagne rises in the Alpes Maritimes province of South Eastern France to the north of Cannes, and is used, by reason of its clear spring water, to supply the town with drinking water from an intake near the village of St. Césaire. The power-station is situated immediately above this intake, and utilizes a fall of about $348 \mathrm{~m}$. (1,142 feet) of the Siagne. The water is taken from a weir on the upper reaches of the river by a conduit and tunnel to a balancing reservoir above the powerhouse, partly blasted out of the rock and partly formed by a large retaining wall. The Siagne discharges an average volume of about $3 \mathrm{~m}^{3}$. (105 cubic feet) per second at the intake weir, and thus, with the fall of $348 \mathrm{~m}$. (1,142 feet), provides an absolute output of 14,000 h.p. The Compagnie de l'Energie Electrique du Littorale Méditerranéen has developed this power by means of five units of $2,000 \mathrm{kw}$. maximum each, of which one is held as a reserve.

The Siagne power-station provides a specially interesting and most instructive case of high-pressure pipe-lines, and has demonstrated in a most drastic manner what the consequences of incorrect design can be. The original pipe-line had to be abandoned after a few months' running on account of unsatisfactory working of the plant, and an entirely new pipe-line had to be built on totally different principles, in spite of the fact that the chief dimensions of the pipes were perfectly correct and amply sufficient for the conditions of head and discharge, and moreover were not altered in the second pipe-line.

Two parallel pipes were provided, each $900 \mathrm{~mm}$. $(35 \cdot 4$ inches) diameter, built of single pipes about 6 metres long of riveted plate of from 4 to $25 \mathrm{~mm}$. thickness, the individual pipes being riveted together in situ. The pipes rested on masonry pedestals and closely followed the surface of the ground, so that the pipe-line consisted of a large number of inclines and angles in every direction. Fig. 19, Plate 46, clearly shows how the two pipe-lines were brought down to the power-house. About $40 \mathrm{~m}$. vertically 
above the latter, they formed a kind of distributing pipe from which the connecting-pipes branched off to the turbines. Above this distributing pipe, the pipe-lines rose at a very steep angle, in places almost vertically, to a point 90 metres below the intake. From this point they turned to the left and led for a considerable distance at a very slight gradient to the penstock chamber.

The principal faults in the arrangement of this line were as follows :-

(1) Too great a length of the upper portion, under low pressure, with pipes of small thickness, whereby a continual working or respirating phenomenon became apparent in this part of the pipe-line.

(2) Insufficient fixing or anchoring of the pipes in the lower portion of the line, and a most curious position of the distributing pipe, in which very harmful vibration combined with displacement of the pipes could take place, on sudden variations of watervelocity or shocks in the pipe-line; this might easily lead to a burst, especially in the case of riveted pipes.

(3) Unsuitable dimensions of the connecting pipes between distributor and the turbines, with their length too great and their diameter too small, resulting in considerable accentuation of the pressure variations.

Each pipe-line formed one single rigid piece from top to bottom, and no provision was made to allow for expansion and contraction, such as the insertion of expansion-joints. Expansion due to temperature changes in an exposed pipe-line is, however, unavoidable, and if no arrangements are made to allow of longitudinal motion, then additional stresses will be set up in the pipe walls that will be difficult to foresee, and will cause resultant stresses which may under certain conditions have a disastrous effect.

It must be mentioned here that French engineers in general build pipe-lines on this principle, that is, without expansion-joints, and that a large number of such high-pressure pipe-lines are now in continuous operation in France. This design must, nevertheless, be characterized as irrational, especially in view of the demands made, at the present day, on the pipe-line of a central station with continually and rapidly changing water-velocities. 
Shortly after starting up the works, a burst occurred at about the middle of one of the pipe-lines, probably owing to some such sudden variation in the pipe velocity. A longitudinal riveted joint was torn open for a length of 2 metres, and the water suddenly streamed with such velocity from the gap that a large part of the upper section of the pipe was completely flattened by the vacuum which was produced, in spite of large air-pipes at the penstock chamber. Exhaustive investigation led to the final decision to replace the entire existing pipe-lines by others over a quite different route.

The new line has been in continuous operation since the spring of 1908. It consists of two parallel pipe-lines of almost the same dimensions as the old, but differs therefrom in that it passes straight down the side of the mountain from the penstock chamber to a point about 30 to 40 metres above the power-house, when it turns round and passes towards the latter through a tunnel.

The upper part of the pipe-line was made as short and as steep as possible and the lower arranged longer in proportion. The whole line is divided into six straight sections; the angle points between them are formed into main anchorages (fixed points) of solid concrete masonry into which the pipe-bends are rigidly bedded. An expansion-joint is placed below each fixed point. The intermediate concrete pedestals supporting the pipe-line are laid at a uniform distance of $7.90 \mathrm{~m}$. apart.

Fig. 21, Plate 47 , is a view of the lower part of the pipe-line immediately before the tunnel entrance, showing two fixed-point anchorages. The upper of these anchorages has the pipes completely grouted in, and is shown during construction in Fig. 20, Plate 46 ; the lower is treated as an intermediate fixed point on account of its short distance from the upper, and the pipes are only bolted down to the concrete foundation. The next main fixed point below the preceding, and at the same time the last on the line, is situated in the tunnel which emerges at the power-house. This main anchorage takes up the whole thrust of the pipe-lines, and the horizontal continuation of the latter which extends along the power-house wall to feed the turbines has free ends. 
Quite short conical pipes of 400 to $500 \mathrm{~mm} \cdot\left(15 \frac{3}{4}-19 \frac{3}{4}\right.$ inches) diameter connect each main pipe to the five turbines, and are fitted with sluice-valves so that the latter may be run separately from either pipe-line. In normal running the two pipe-lines are thus connected together, and pressure variations due to any one generating unit distribute themselves over the cross-section of both pipes; they can also be isolated at any time when required, or either pipe-line may be shut down and all the turbines kept running on one only.

In fact the station was run at first from one new pipe-line alone without difficulty, while the second was being erected, the object in doing so being to minimize the time during which the plant was kept idle after the accident to the old line.

These pipe-lines were also riveted together in situ, the upper portion, up to $13 \mathrm{~mm}$. ( $\frac{1}{2}$ inch) thickness, being of riveted pipe, and the remainder of pipes lap-welded by the water-gas process. The total length of the pipe-line is $876 \mathrm{~m}$. (2,870 feet) composed of three sizes of pipes of $950,900,850 \mathrm{~mm}$. $\left(37 \frac{1}{2}, 35 \frac{1}{2}\right.$, and $33 \frac{1}{2}$ inches $)$ diameter respectively. The thickness varies between 7 and $22 \mathrm{~mm}$.

Each pipe is fitted at the penstock chamber with an automatic hydraulic stop-valve, also arranged to be operated electrically from the power-house by means of a solenoid. This automatic hydraulic valve can be set to close at any desired maximum discharge of water; if for any reason the discharge exceeds the limit, the intake opening closes at once.

The whole erection of the new pipe-line was finished in six months. The result as compared with the old pipe-line was as expected. The extraordinary surges and resonance effects of the pressure shocks, especially the visible movement and trembling of the pipes, completely disappeared. No disturbance or irregularity could be observed in the pipe-line eren with severe and sudden load variations during running.

The five 2,000 kw. (max.) machines installed in the powerhouse run at 375 revolutions per minute. The turbines are Escher, Wyss and Co.'s impulse-wheels of 2,800 h.p. maximum cutput, having each one regulating needle-nozzle. They are fitted. 
with automatic speed-regulators and pressure-relief valves, both operated by the pipe-line water, which is exceptionally clean and could therefore well be used. The rigid coupling which connects turbine and generator is arranged as a fly-wheel to increase the rather small fly-wheel effect of the generators, in view of the exceedingly close governing guarantees required.

The Siagne power-station is used as one of the hydro-electric plants which feed the high-tension system supplying power to Nice and Cannes.

Conclusion.-The water-carrying system of a high-pressure hydraulic power scheme consists of two parts: the low-pressure part to cover most of the horizontal distance between the lake or river-intake and the power-house, and the high-pressure part to give the operating head for the station. The high-pressure pipeline represents one of the most costly items of the plant, and is therefore made as short as possible by taking the low-pressure conduit to the nearest advantageous point above the power-house. There are two main types of this conduit: that in which water flows under pressure, and that with water flowing freely in an open flume. Both these types have been illustrated in this Paper. The former may be further subdivided: into (1) the pressure-tunnel arrangement leading to a deep penstock-chamber, as in the case of the Tyssedalen and Brusio installations; and (2) the low-pressure feeder-pipe arrangement connecting to a receiver with a stand-pipe, as at Necaxa and Rio de Janeiro. Both of these systems allow of the total head available at any time in the reservoir to be utilized, even with large variations in water-level.

The type of conduit with open flume cannot, however, utilize any head in the reservoir, and this must be lost. In the case of a long conduit a balancing reservoir must also be constructed to provide for any sudden increase in the load, since the open flume will not draw a greater volume of water to supply a greater demand, as happens automatically with the pressure conduit. This case is illustrated in the Siagne power-station. Another example is the well-known Kinlochleven plant of the British Aluminium Co. in 
Scotland. The choice of the arrangement of conduit most suitable for a power scheme depends entirely on the particular conditions of the works, and no rule can be laid down.

The best proof of the great interest now taken in water-power development works by mechanical and all engineers lies in the list of visits to large modern hydro-electric stations given in the programme to be followed by the members of this Institution, which is honouring Switzerland with its Summer Meeting this year.

Members of the Institution of Mechanical Engineers are indeed the representatives "par excellence" of steam and steam-power. Water power, the "White Coal" of the mountains, will hardly be of much importance in their own country, compared with that all powerful "Black Queen of Energy" of which they have in abundance; but it may indeed play a very great part in the development of the resources of the vast Colonial Possessions composing the British Empire.

The Paper is illustrated by Plates 38 to 47 and 6 Figs. in the letterpress.

[The Discussion on this Paper was combined with that on the Paper by Professor Prášil, ard commences on page 667.] 
HIGH-PRESSURE WATER-POWER WORKS. Plate 38.

Fig. 2. Intake Screens at Tenango Reservoir and Entrance of Tunnel to Necarar Lake.

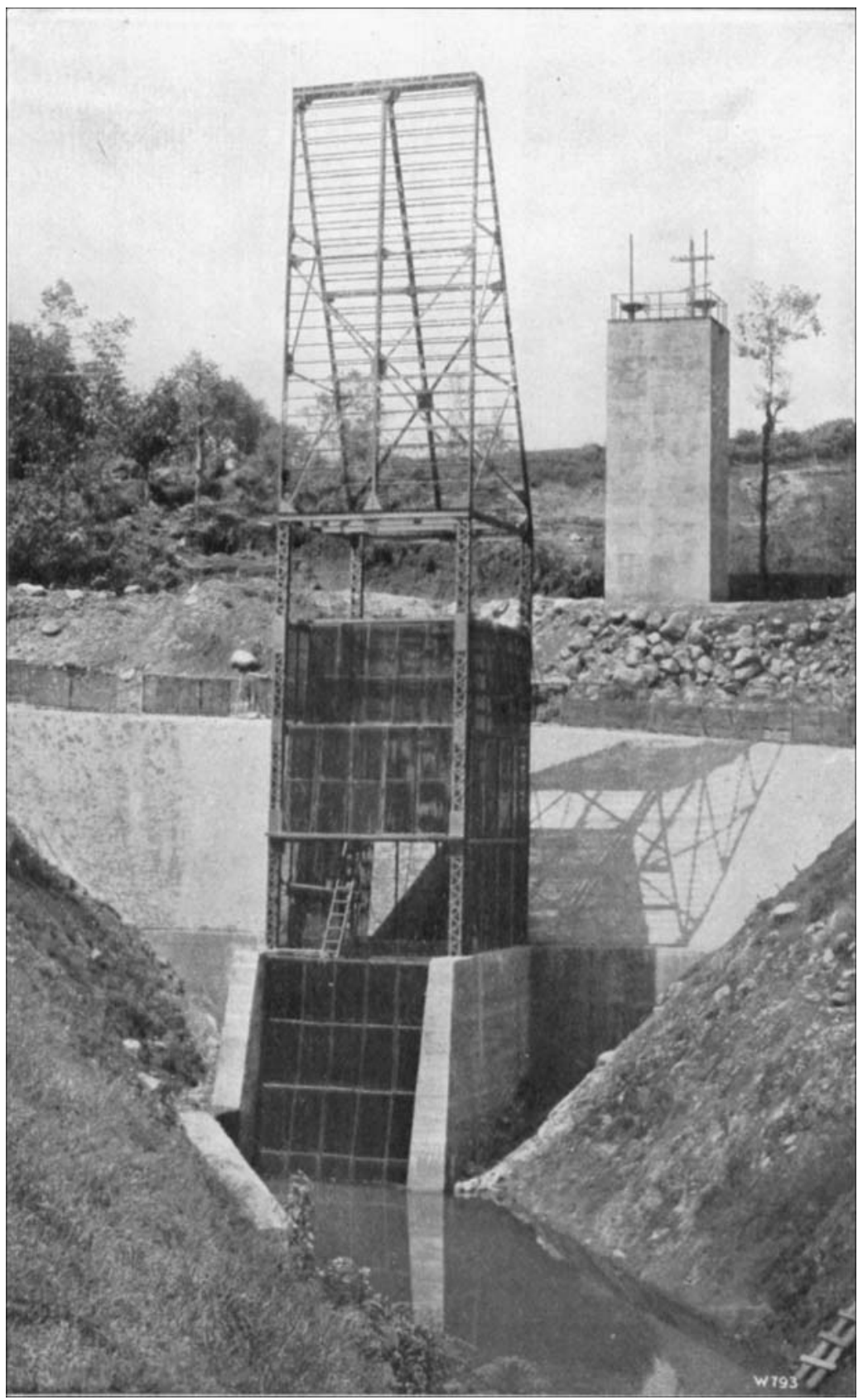

Downloaded from pme.sagepub.com at University of Birmingham on June 8, 2016 
Fig. 3. Necaxa Power House with six 11,000 H.P. Turbines in operation, and showing Excavation proceeding for the two 16,000 H.P. Units.

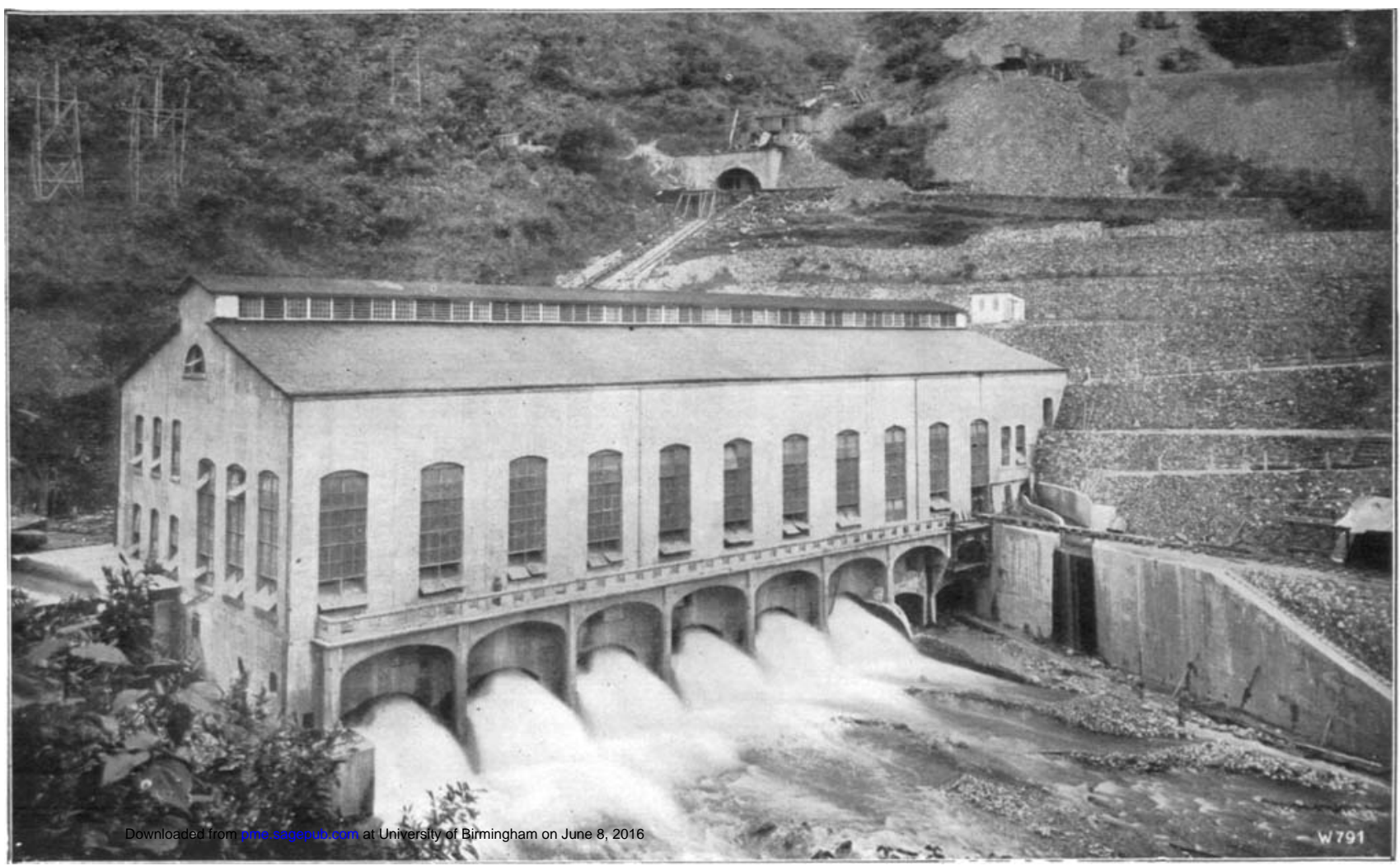


HIGH-PRESSURE WATER-POWER WORKS. Plate 40.

Rio de Janeiro.

Fig. 5. The Spillway Completed.

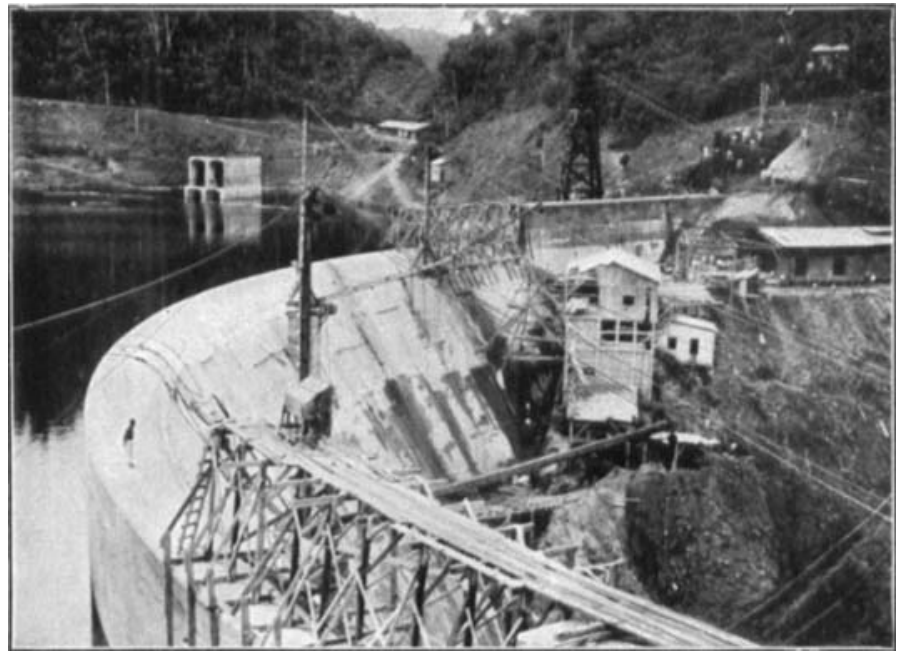

Fig. 6. The Water Intake during Construction.

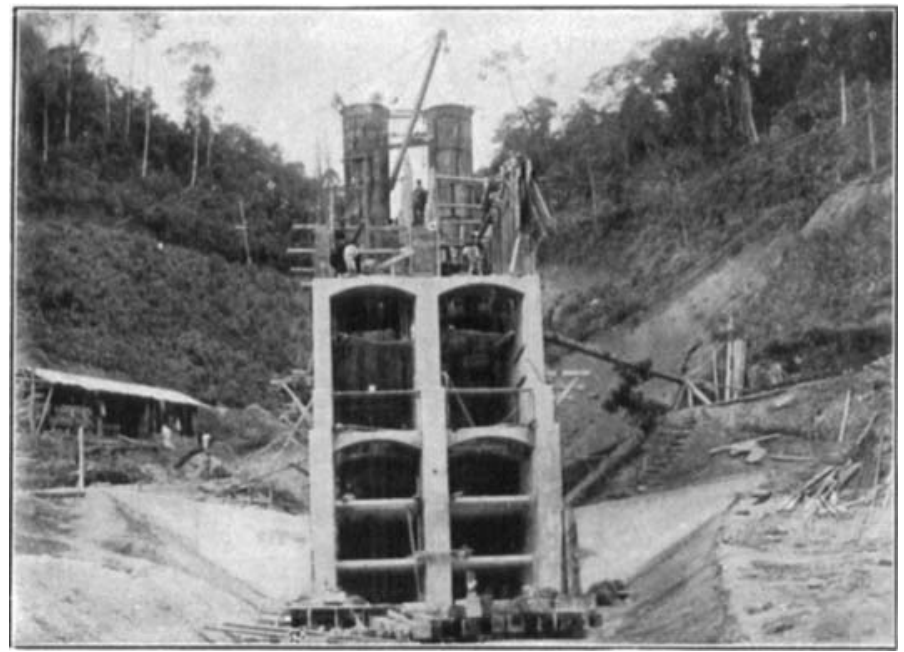


HIGH-PRESSURE WATER-POWER WORKS. Plate 41.

Rio de Janeiro.

Fig. 7. The Siphon.

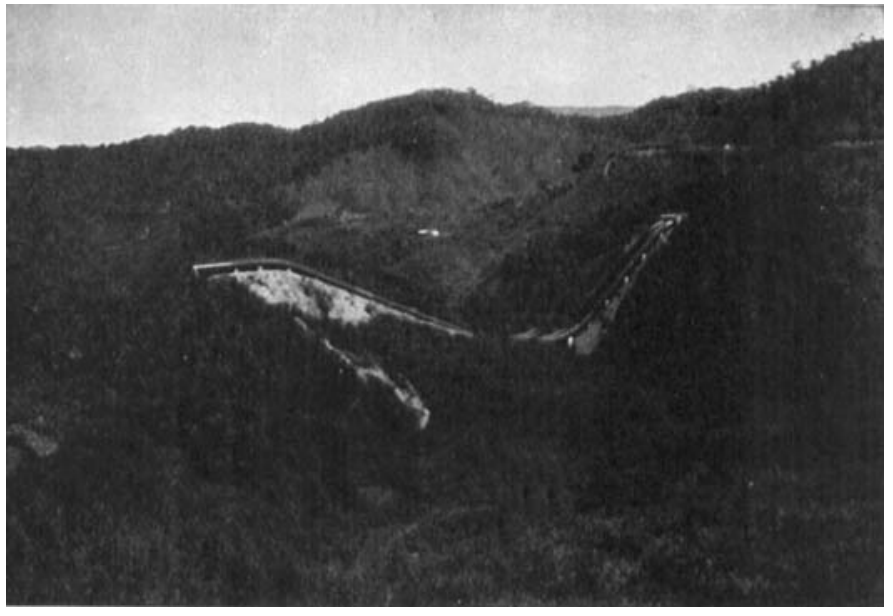

Fig. 8. Power-House and High-P'ressure Pipe-Linc.

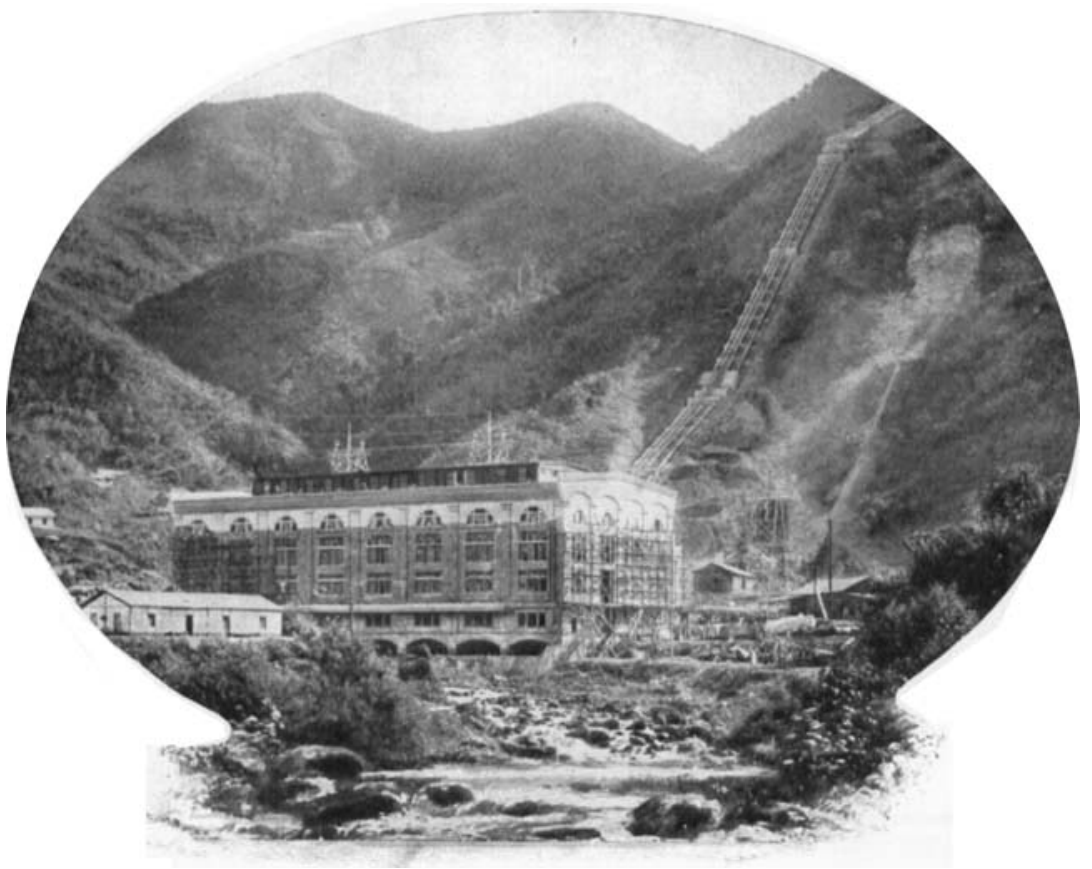

Downloaded from pme.sagepub.com at University of Birmingham on June 8, 2016

Mechanical Engineers 1911. 


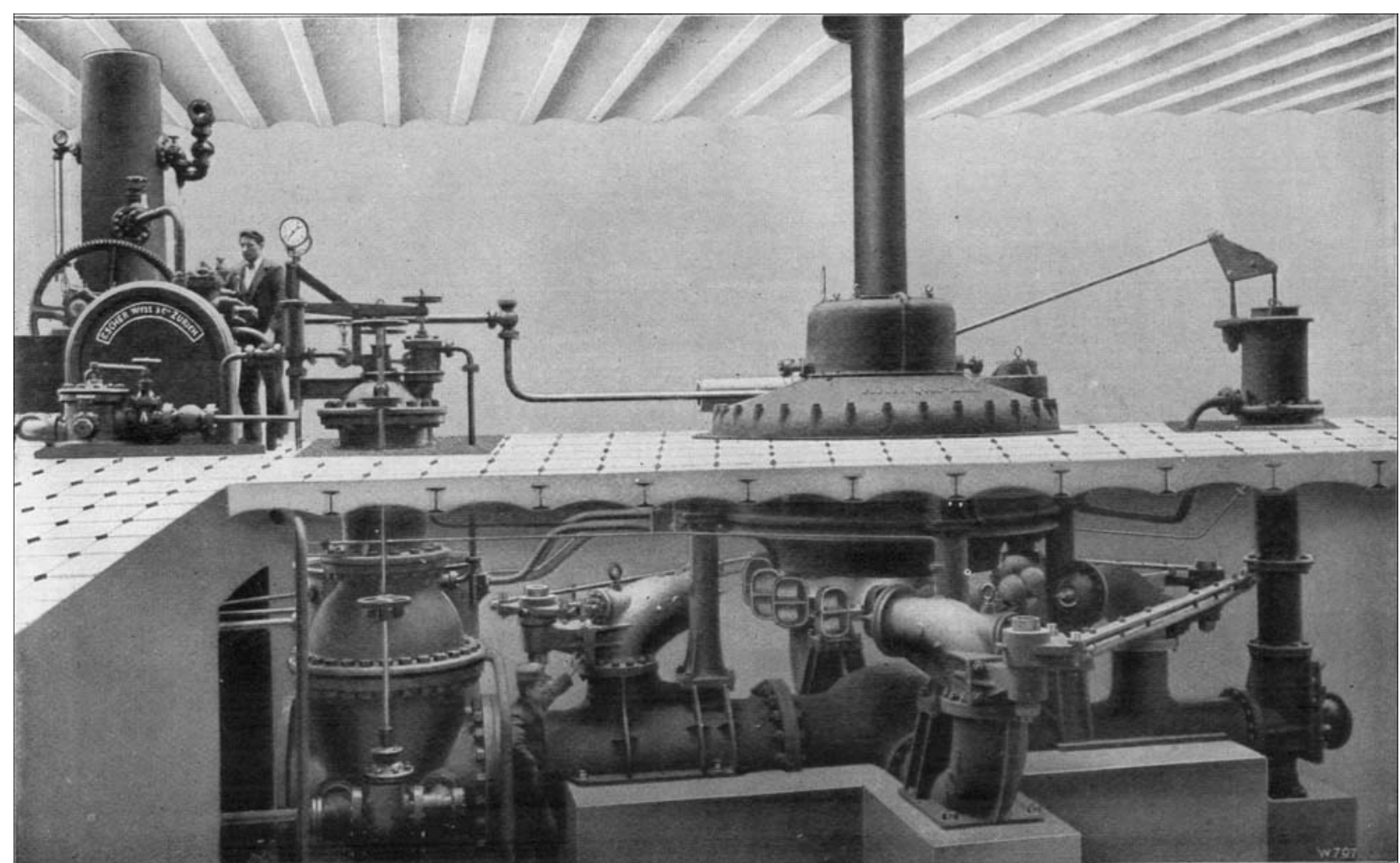


HIGH-PRESSURE WATER-POWER WORKS. Plate 4.3. Tyssedalen.

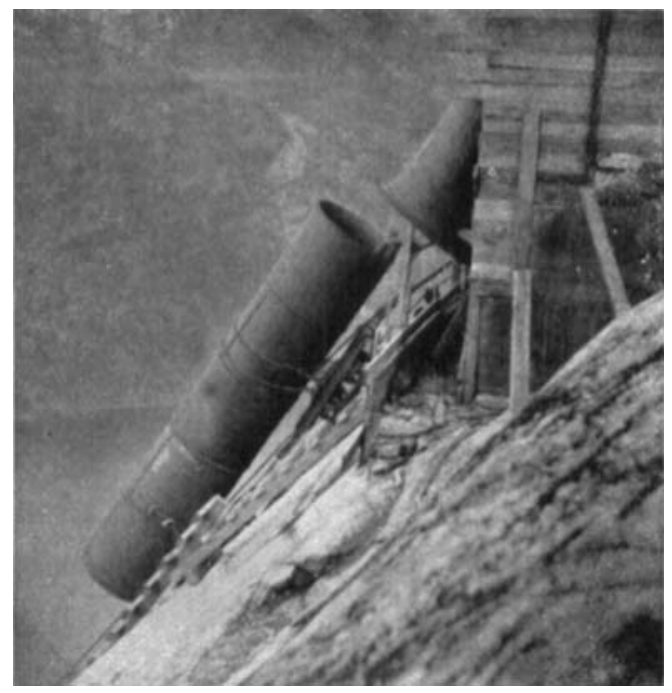

Fig. 10.

\section{Position of $a$}

Main Anchorage

shorving

Pipe Transport.

Fig. 11. A difficult Part of the Pipe-Line.

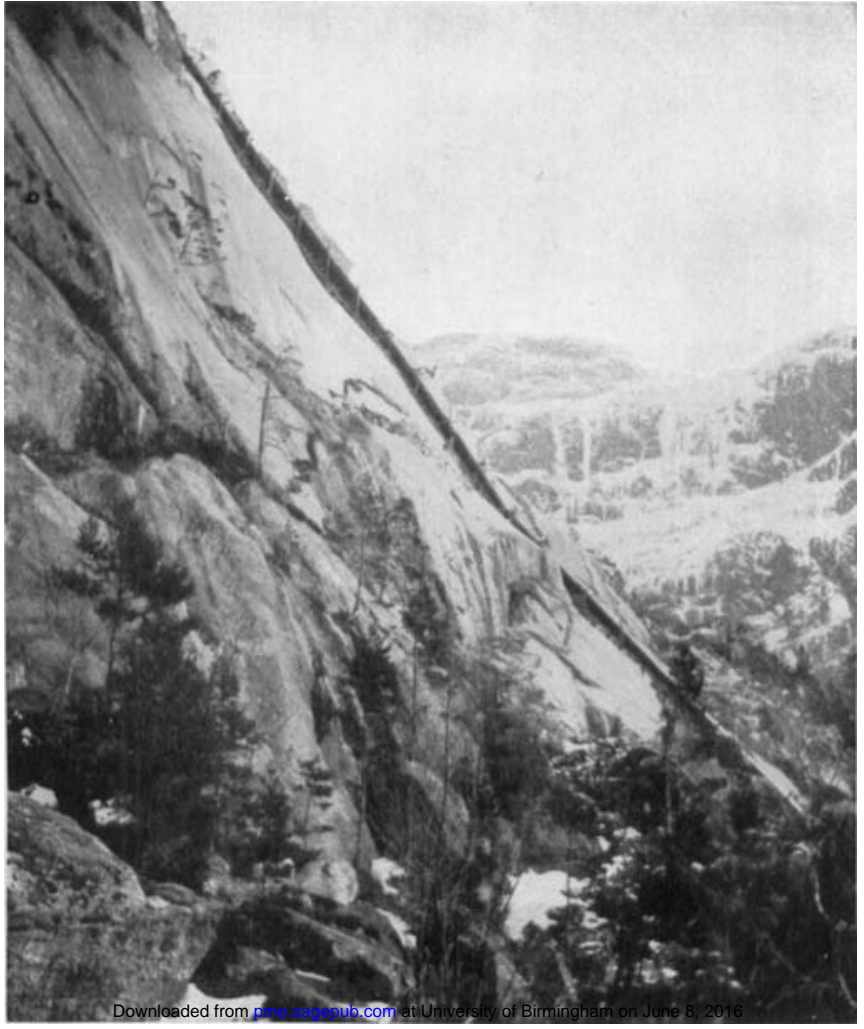


HIGH-PRESSURE WATER-POWER WORKS. Plate 4 . Tyssedalen.

Fig. 12. 4,800 H.P. Turbine and Regulating Gear.

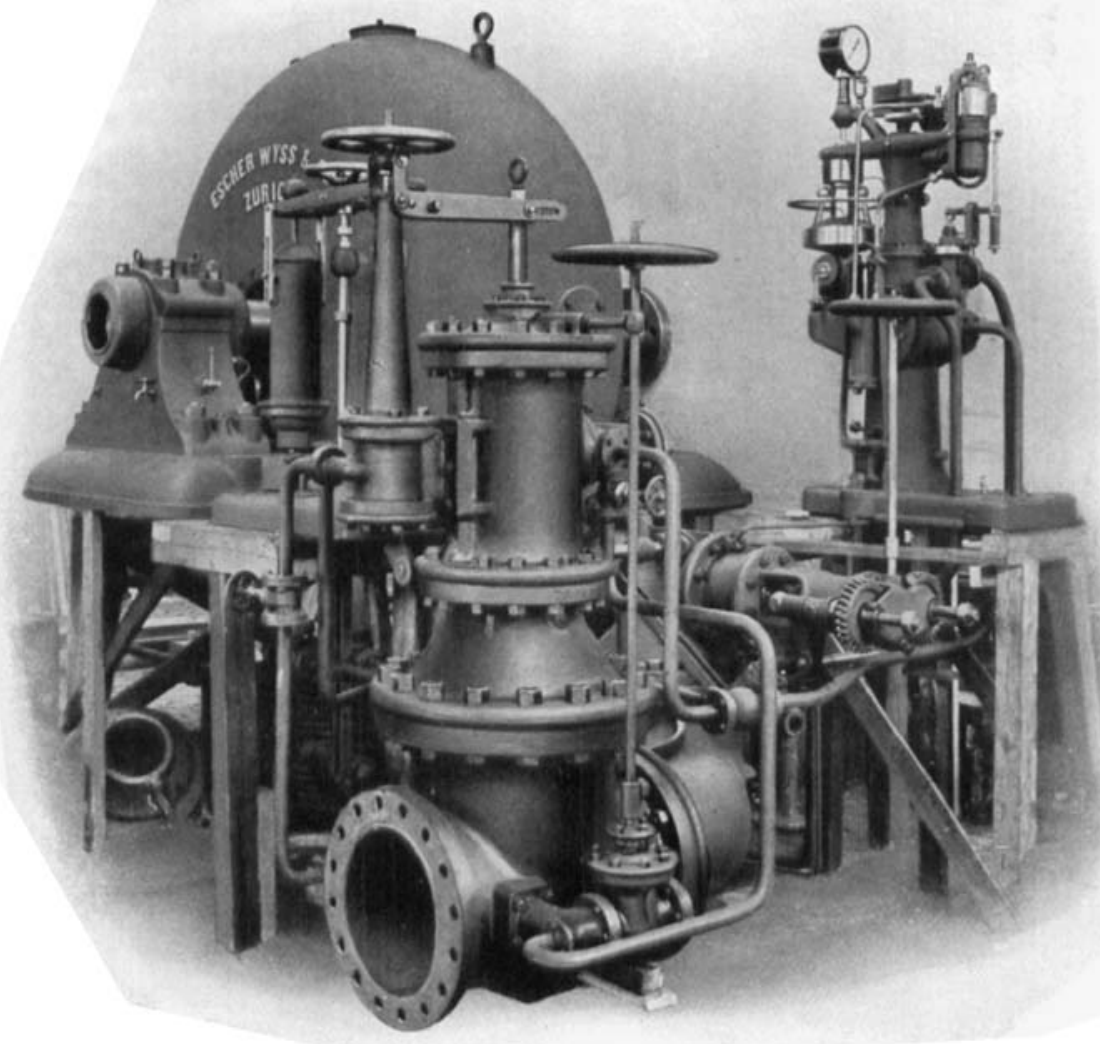

Fig. 13. 4,800 H.P. Turbine and Governor.

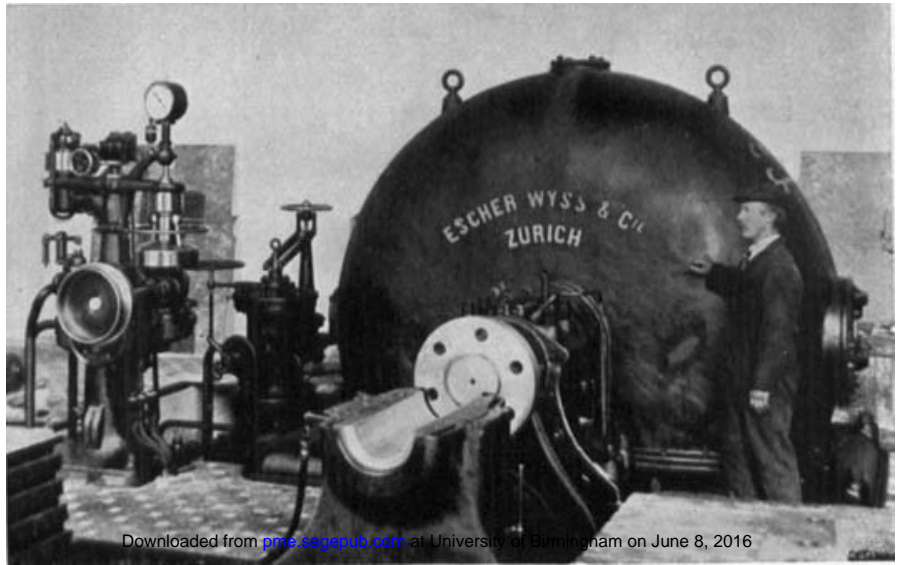


HIGH.PRESSURE WATER-POWER WORKS. Plate 45.

Brusio.

Fig. 17. The Pipe-Line and Main Anchorages.

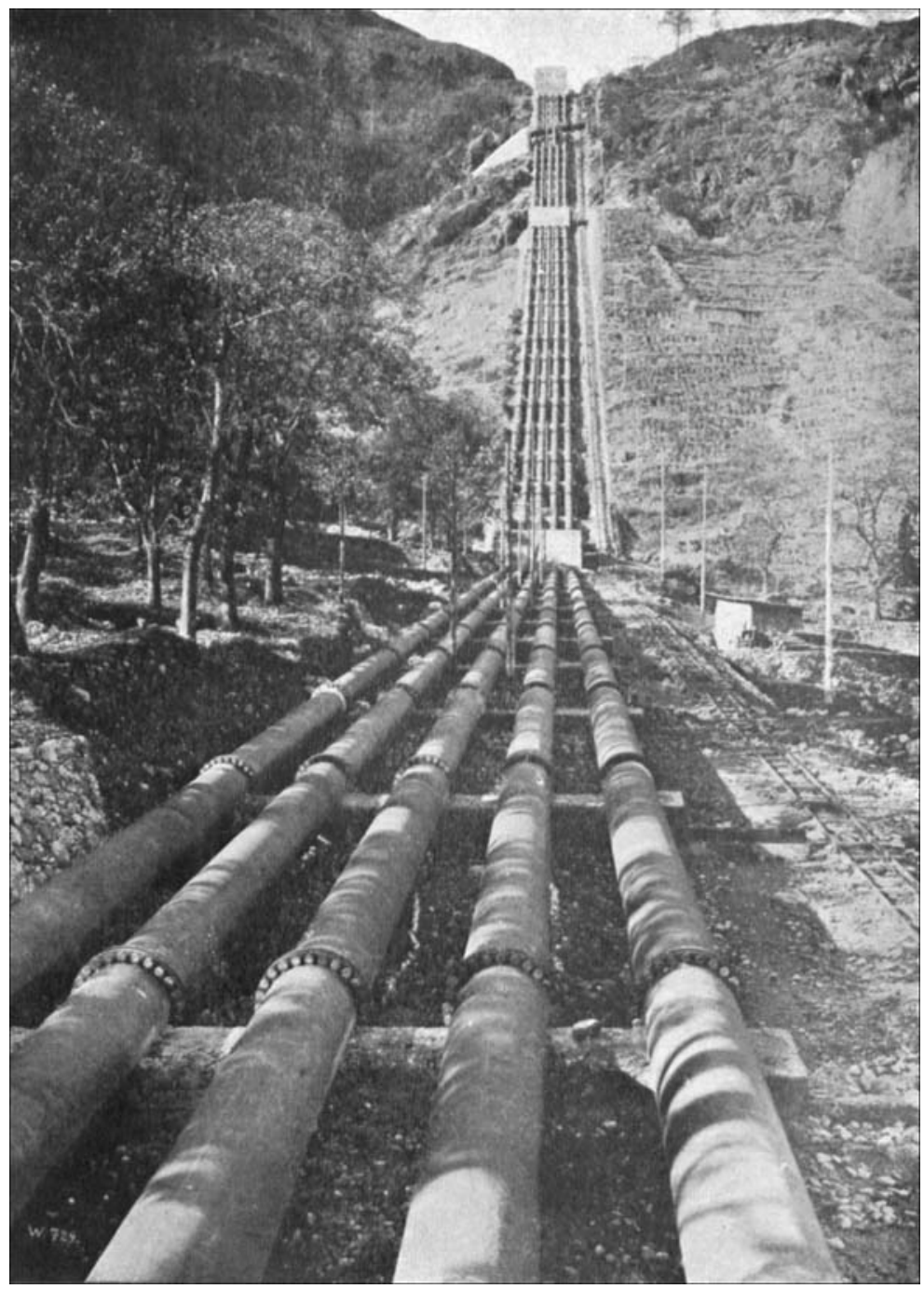


HIGH-PRESSURE WATER-POWER WORKS. Plate 46. Siagne.

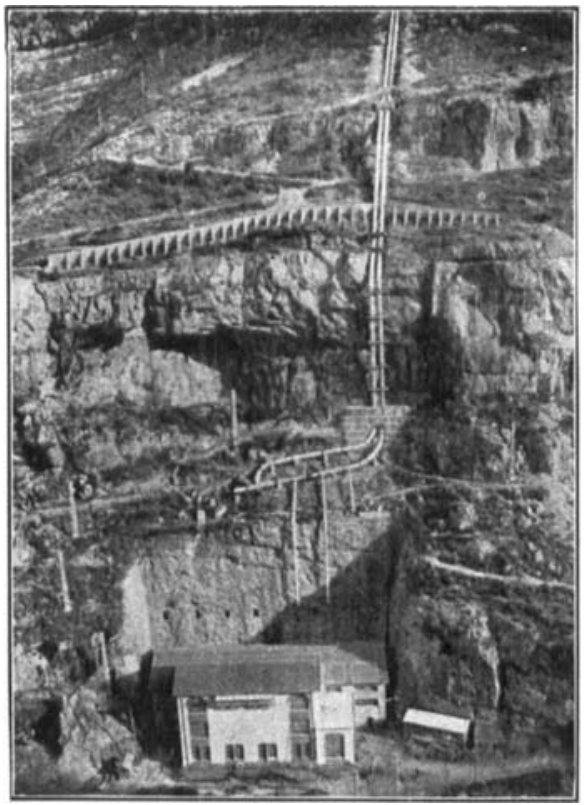

Fig. 19.

The Lower Part

of the

Old Pipe-Line

near the

Power-House.

Fig. 20.

Main Anchorage

on

New Pipe-Line

in course of

Construction.

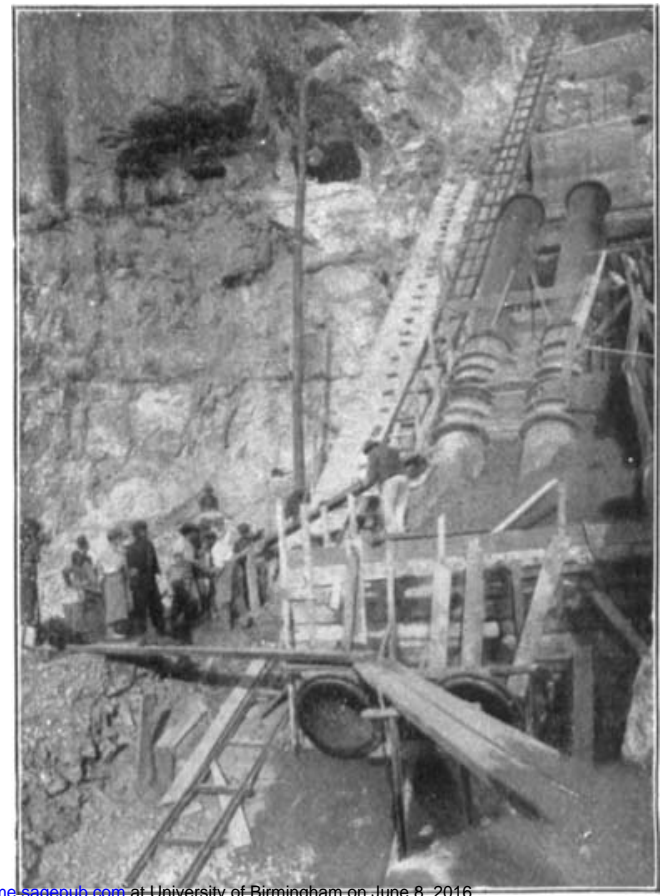

Downloaded from pme 
HIGH-PRESSURE WATER-POWER WORKS. Plale 47.

Siagne.

Fig. 21. Lower portion of Ncw Pife-Linc.

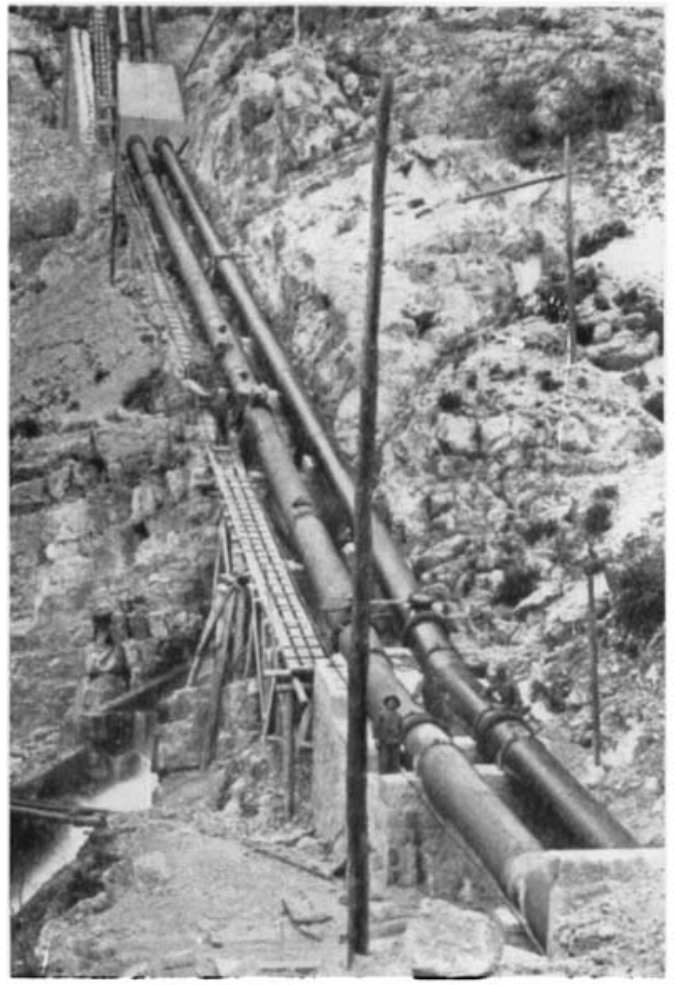

(.Mr. A. Scott-Hanscy's communication.)

Fig. 24. Power Station, Síalgfos.
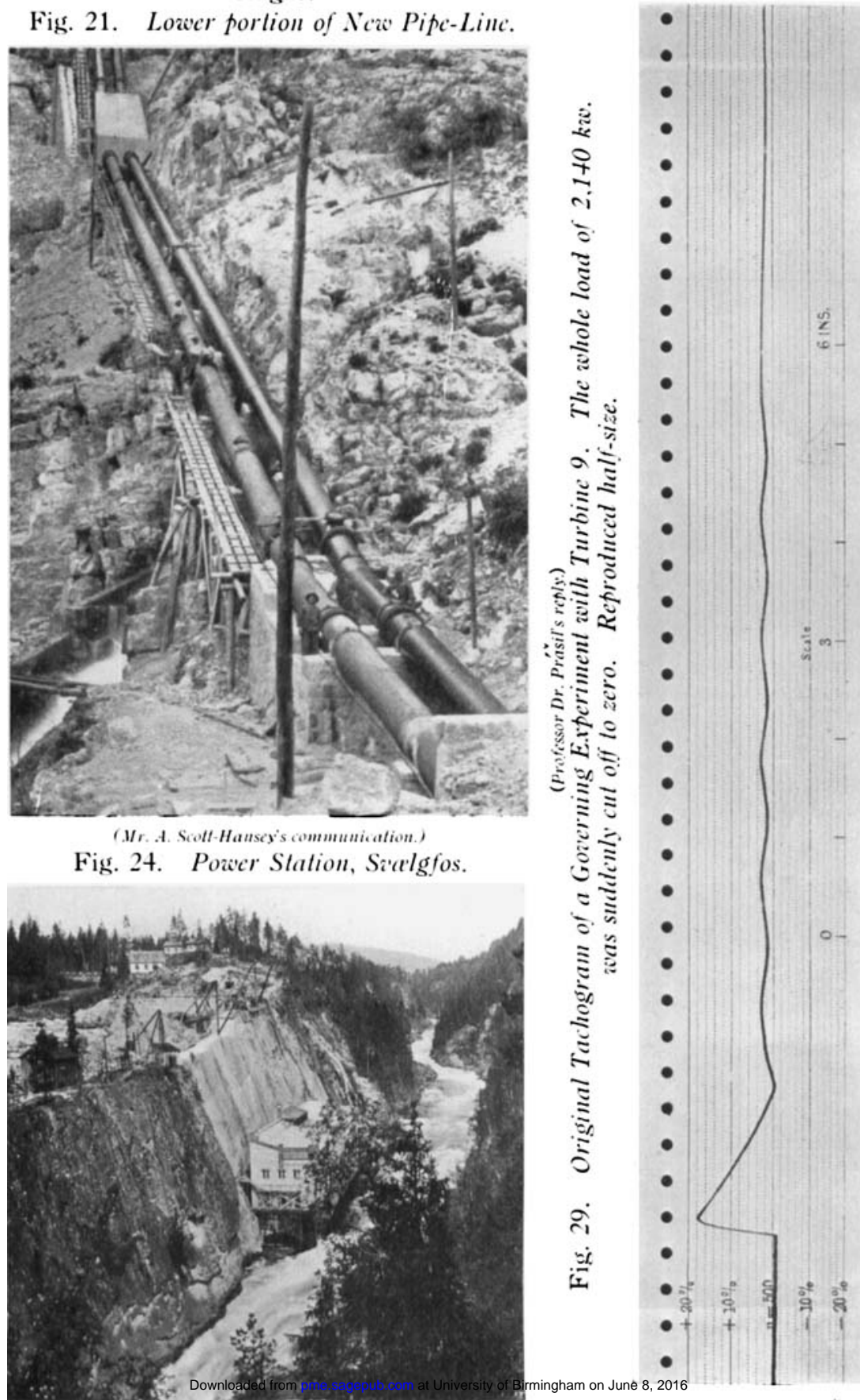

Mechanical Engineers 1911. 